Nevada

Environmental

Restoration

Project

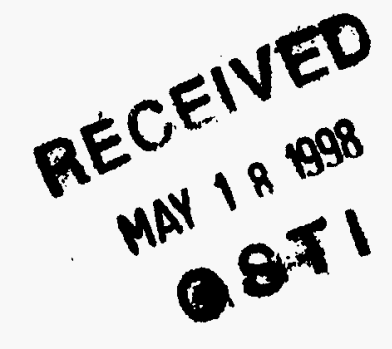

Corrective Action

Investigation Plan for

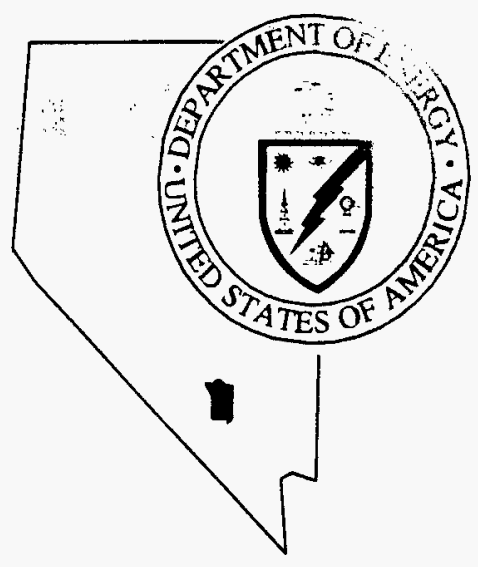

Corrective Action Unit 340,

Pesticide Release Sites,

Nevada Test Site, Nye County, Nevada

Controlled Copy No.:

Revision No.: 0

January 1998

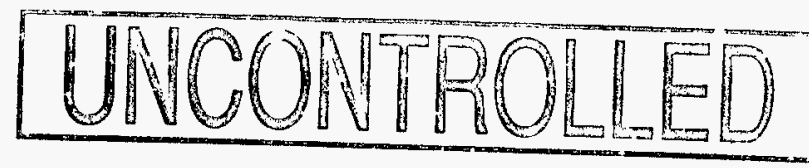

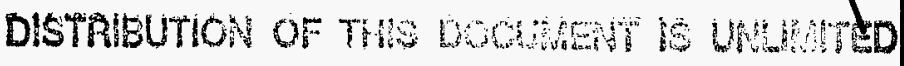

MASTER

Approved for public release; further distribution is authorized.

Environmental Restoration

in 
This report has been reproduced directly from the best available copy.

Available to DOE and DOE contractors from the Office of Scientific and Technical Information, P.O. Box 62, Oak Ridge, TN 37831; prices available from (423) 576-8401.

Available to the public from the National Technical Information Service, U.S. Department of Commerce, 5285 Port Royal Road, Springfield, VA 22161, telephone (703) 487-4650. 


\section{CORRECTIVE ACTION INVESTIGATION PLAN FOR CORRECTIVE ACTION UNIT 340, PESTICIDE RELEASE SITES, NEVADA TEST SITE, NYE COUNTY, NEVADA}

DOE Nevada Operations Office

Las Vegas, Nevada

Controlled Copy No.:

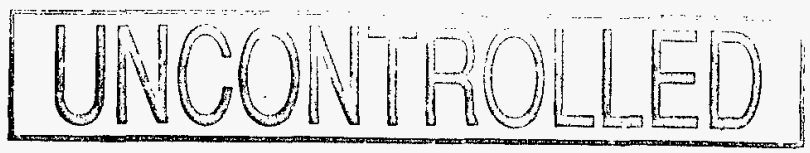

Revision No.: 0

January 1998

Approved for public release; further distribution is authorized. 


\section{DISCLAIMER}

This report was prepared as an account of work sponsored by an agency of the United States Government. Neither the United States Government nor any agency thereof, nor any of their employees, makes any warranty, express or implied, or assumes any legal liability or responsibility for the accuracy, completeness, or usefulness of any information, apparatus, product, or process disclosed, or represents that its use would not infringe privately owned rights. Reference herein to any specific commercial product, process, or service by trade name, trademark, manufacturer, or otherwise does not necessarily constitute or imply its endorsement, recommendation, or favoring by the United States Government or any agency thereof. The views and opinions of authors expressed herein do not necessarily state or reflect those of the United States Government or any agency thereof. 
CORRECTIVE ACTION

INVESTIGATION PLAN FOR CORRECTIVE ACTION UNIT 340, PESTICIDE RELEASE SITES, NEVADA TEST SITE, NYE COUNTY, NEVADA
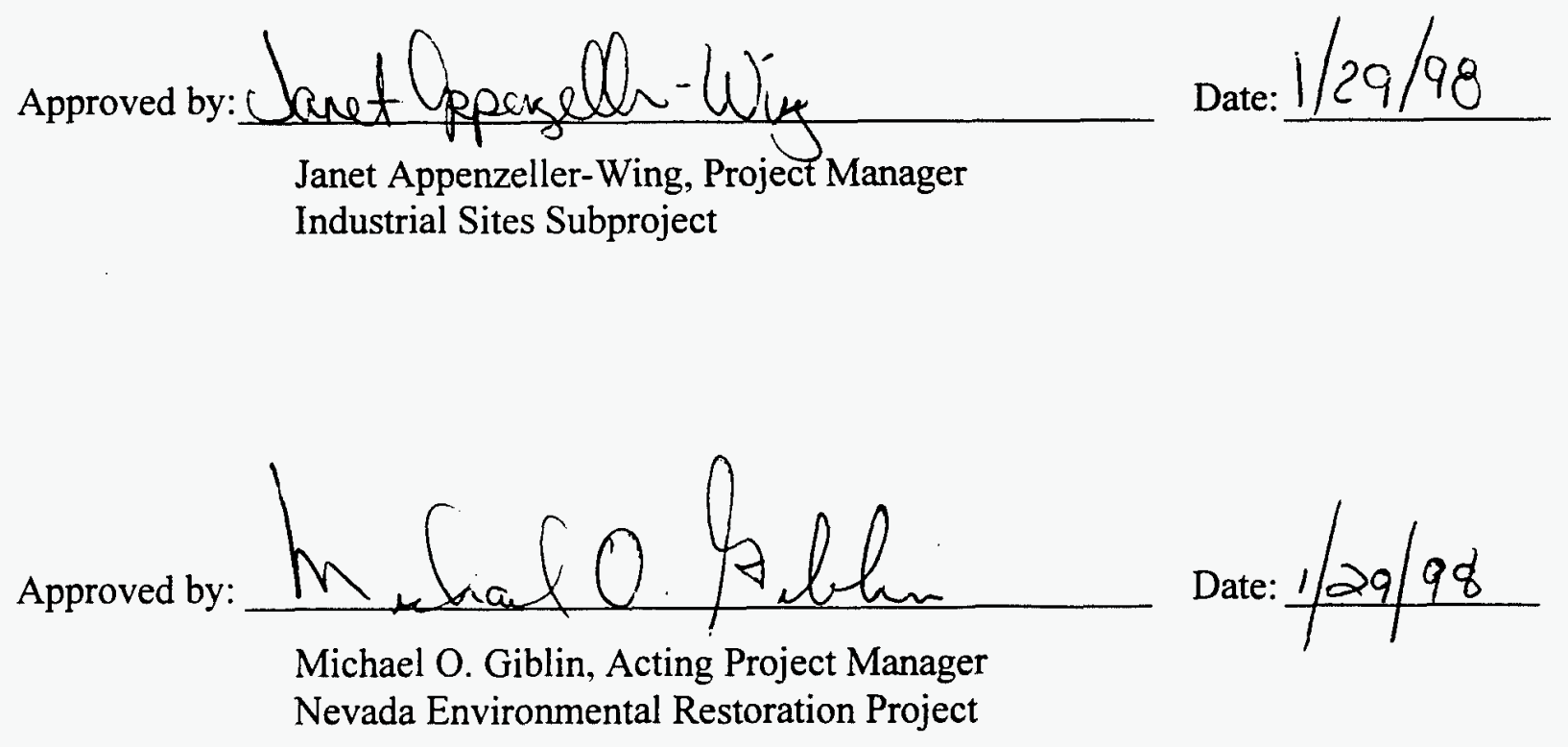


\section{Table of Contents}

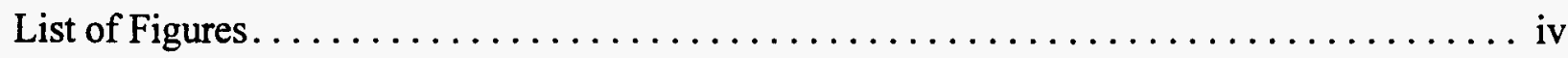

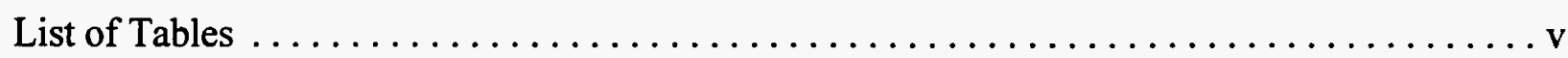

List of Acronyms and Abbreviations $\ldots \ldots \ldots \ldots \ldots \ldots \ldots \ldots \ldots \ldots \ldots \ldots \ldots \ldots \ldots$

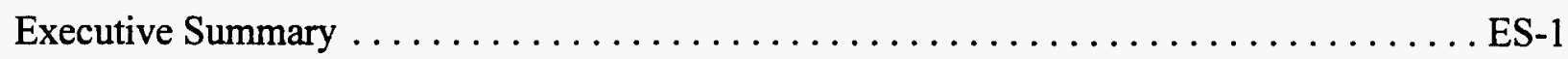

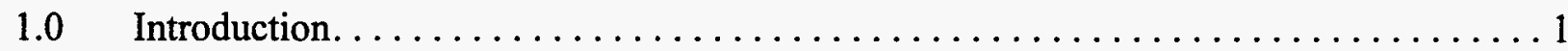

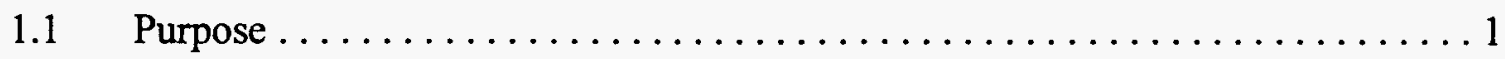

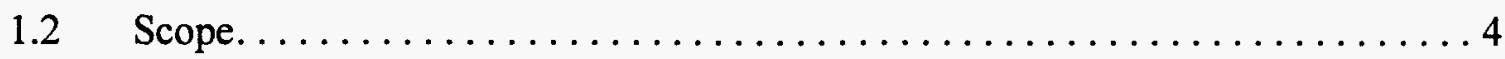

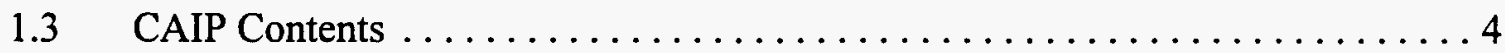

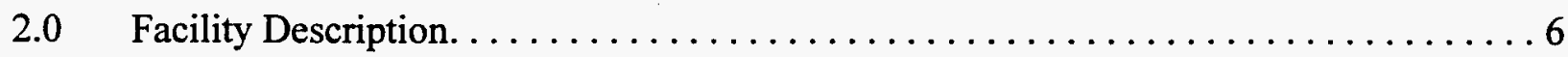

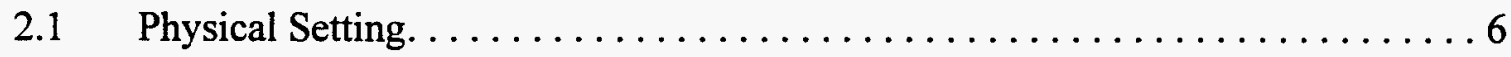

2.1.1 Location and Description of the Investigation Area(s) .........6

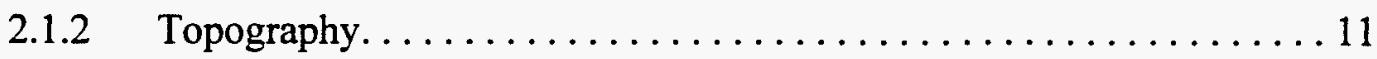

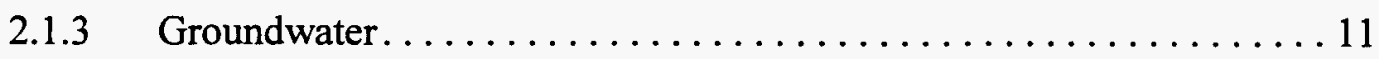

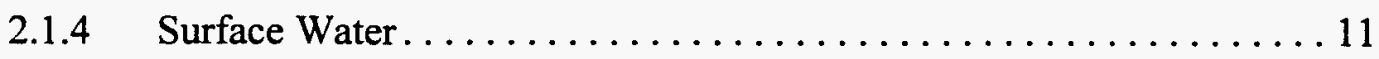

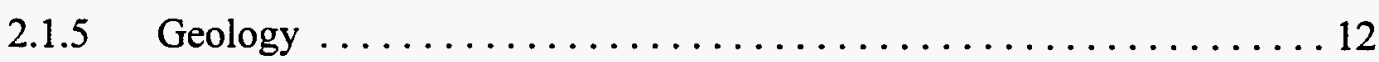

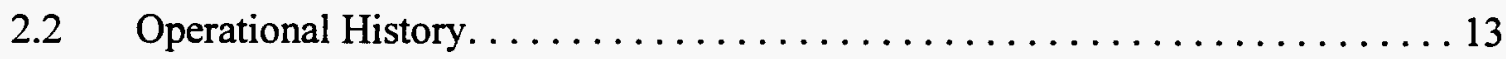

2.2.1 CAS 23-21-01 Area 23 Quonset Hut 800............. 13

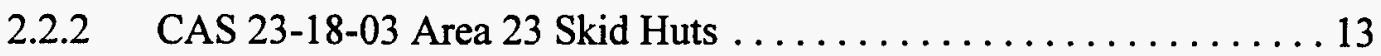

2.2.3 CAS 15-18-02 Area 15 EPA Farm Quonset Hut 15-11 ......... 14

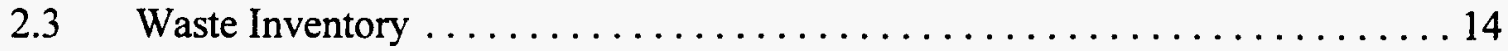

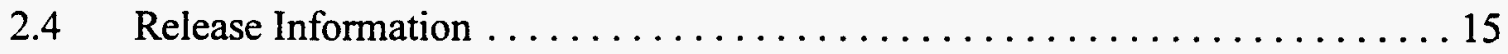

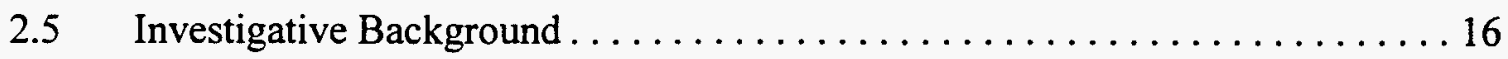

2.5.1 CAS 23-21-01 Area 23 Quonset Hut 800............... 16

2.5.2 CAS 23-18-03 Area 23 Skid Huts .................... 16

2.5.3 CAS 15-18-02 Area 15 EPA Farm Quonset Hut 15-11 ......... 18

2.5.4 National Environmental Policy Act (NEPA) Requirements . . . . . . 18

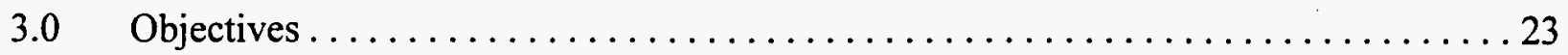

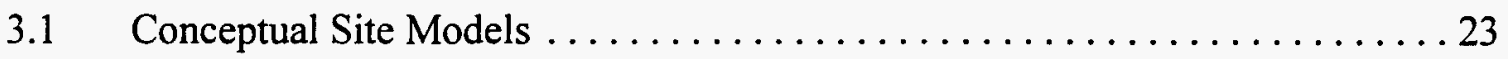

3.1 .1 General Assumptions ........................... 23

3.1.2 Site-Specific Conceptual Model for Quonset Hut $800 \ldots \ldots \ldots \ldots 24$ 


\section{Table of Contents (Continued)}

3.1.3 Site-Specific Conceptual Model for Skid Huts . . . . . . . . . . . 24

3.1.4 Site-Specific Conceptual Model for Quonset Hut 15-11 . . . . . . . 26

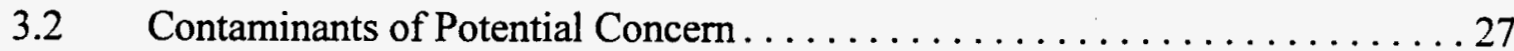

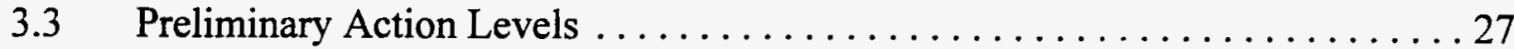

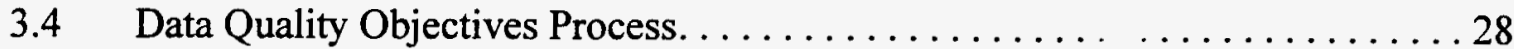

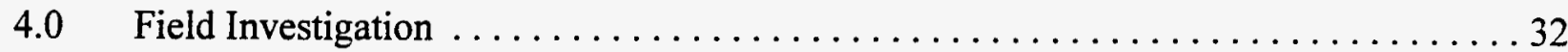

4.1 Two - Staged Sampling Strategy $\ldots \ldots \ldots \ldots \ldots \ldots \ldots \ldots \ldots \ldots \ldots \ldots \ldots \ldots \ldots \ldots \ldots$

4.1.1 Stage I Sampling. . . . . . . . . . . . . . . . . . 33

4.1 .2 Stage II Sampling . . . . . . . . . . . . . . . . . 37

4.2 Sample Collection and Decontamination Procedures. . . . . . . . . . . . 37

4.3 Surface and Shallow Subsurface Soil Samples. . . . . . . . . . . . . 37

4.4 Contingency Subsurface Soil Sampling Methods . . . . . . . . . . . 38

$4.4 .1 \quad$ Trenching. . . . . . . . . . . . . . . . . . . 38

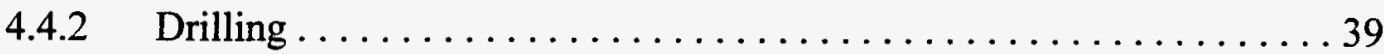

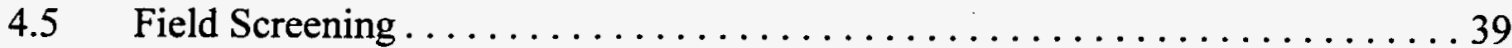

$5.0 \quad$ Waste Management. . . . . . . . . . . . . . . . . . . . . 40

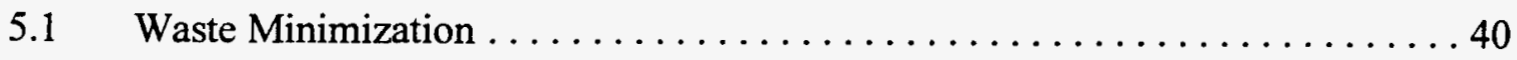

5.2 Potential Waste Streams . . . . . . . . . . . . . . . . . . 41

5.3 Investigation-Derived Waste Management $\ldots \ldots \ldots \ldots \ldots \ldots \ldots \ldots \ldots \ldots$

$5.3 .1 \quad$ Sanitary Waste. . . . . . . . . . . . . . . . . . 43

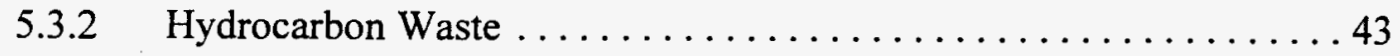

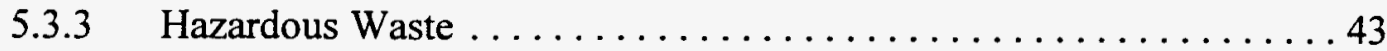

$6.0 \quad$ Duration and Records Availability . . . . . . . . . . . . . . . . . 44

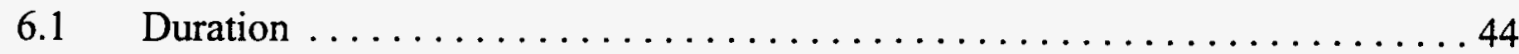

6.2 Records Availability . . . . . . . . . . . . . . . . . . . 44

$7.0 \quad$ References................................. 45

\section{Appendix A - Data Quality Objectives Process Summary}

A.1.0 Introduction. 


\section{Table of Contents (Continued)}

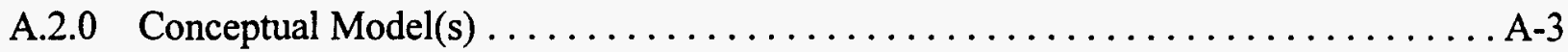

A.2.1 Contaminants of Potential Concern $\ldots \ldots \ldots \ldots \ldots \ldots \ldots \ldots \ldots \ldots$ A-3

A.2.2 Conceptual Site Model(s) $\ldots \ldots \ldots \ldots \ldots \ldots \ldots \ldots \ldots \ldots \ldots \ldots \ldots \ldots$

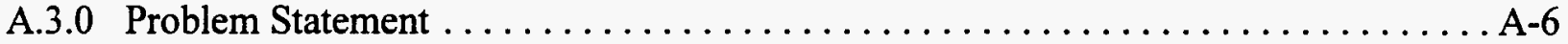

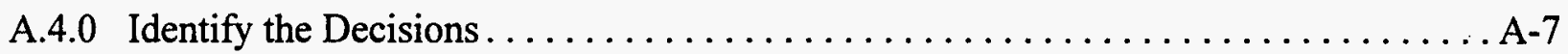

A.5.0 Inputs: Information Needed to Resolve the Decisions . . . . . . . . . . . . A-8

A.6.0 Define the Study Boundaries and Constraints . . . . . . . . . . . . . . A-9

A.6.1 Geographic Investigation Area ....................... A-9

A.6.2 Spatial and Temporal Boundaries...................... A

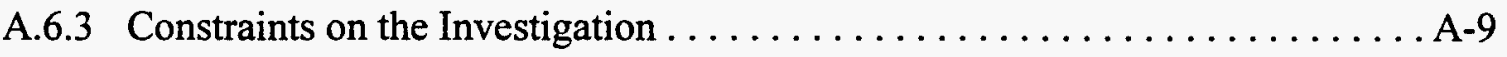

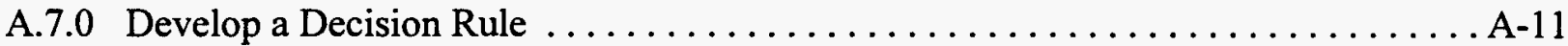

A.7.1 Stopping points and notification $\ldots \ldots \ldots \ldots \ldots \ldots \ldots \ldots \ldots \ldots \ldots \ldots \ldots \ldots \ldots$

A.7.2 Contingency plans. .........................

A.7.3 Rescope, Modify, or Continue Investigation ................. A-11

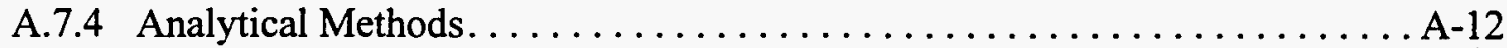

A.7.5 Sampling methods and investigative approach................ A-12

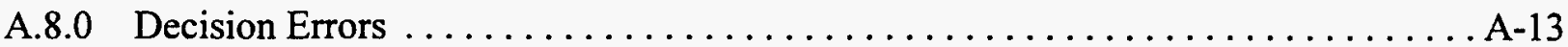

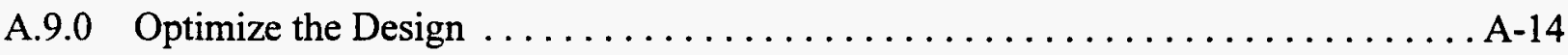

A.9.1 Stage I Sampling ..........................

A.9.2 Stage II Sampling $\ldots \ldots \ldots \ldots \ldots \ldots \ldots \ldots \ldots \ldots \ldots \ldots \ldots \ldots \ldots \ldots \ldots \ldots \ldots \ldots, 14$

\section{Appendix B - Project Organization}

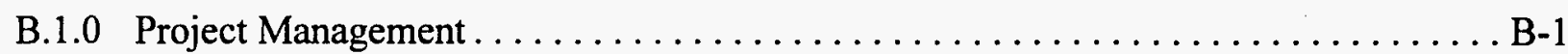




\section{List of Figures}

Number

Title

Page

1-1 Location of the Nevada Test Site, Nye County, Nevada. . . . . . . . . . . . . 2

1-2 General Location of the Area 23 and Area 15 Pesticide Release Sites .......... 3

2-1 General Layout of Area 23 Quonset Hut 800 Investigation Area $\ldots \ldots \ldots \ldots \ldots 7$

2-2 Location of the Area 23 Quonset Hut 800 and Skid Huts Investigation Areas.... . . 8

2-3 General Layout of the Area 23 Skid Huts Investigation Area. .............. 9

2-4 General Layout of the Area 15 Quonset Hut 15-11 Investigation Area ........ 10

2-5 Area 23 Quonset Hut 800 Preliminary Surface-Soil Sample Locations

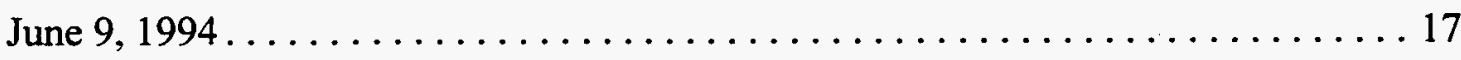

2-6 Area 23 Skid Huts Preliminary Surface-Soil Sample Locations August 27, 1997 . . 19

2-7 Area 15 Quonset Hut 15-11 Preliminary Surface-Soil Sample Locations

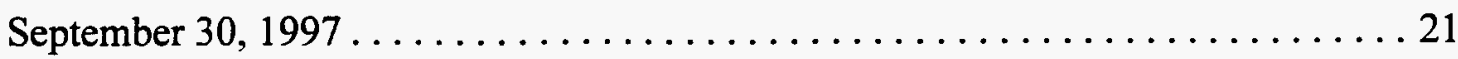

4-1 Area 23 Quonset Hut 800 Planned Sample Locations................... 34

4-2 Area 23 Skid Huts Planned Sample Locations .................... 35

4-3 Area 15 Quonset Hut 15-11 Planned Sample Locations ................. 36 


\section{List of Tables}

Number

Title

Page

1-1 References and Supporting Documentation for the Corrective Action

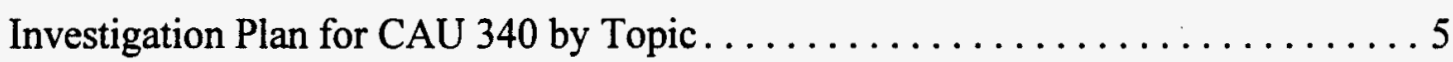

2-1 Area 23 Quonset Hut 800 Summary of the Preliminary Sampling Analytical Results for June 9, 1994, for Total Pesticides . . . . . . . . . . . . . . 18

2-2 Area 23 Skid Huts Summary of Preliminary Sampling Analytical Results August 27, 1997 for Selected Parameters ...................... 20

2-3 Area 15 Quonset Hut 15-11 Summary Preliminary Sampling Analytical Results for September 30, 1997 Total Pesticides and Herbicides .............. 22

3-1 Explanation of Various Aspects that may Potentially Affect or Impact the Corrective Action Site Conceptual Models ................... 25

3-2 Laboratory Analytical Requirements for the CAU 340 Pesticide Release Sites. . . . 29

3-3 Toxicity Characteristic Leaching Procedure Analytical Requirements for the CAU 340 Pesticide Release Sites. . . . . . . . . . . . . . . . . 31

5-1 Action Levels for Investigation-Derived Waste Contaminants. . . . . . . . . . 41

A.1-1 Data Quality Objectives Process Participants and Roles............... A-2

A.5-1 Inputs for the Decision Making Process $\ldots \ldots \ldots \ldots \ldots \ldots \ldots \ldots \ldots \ldots \ldots \ldots$ 


\section{List of Acronyms and Abbreviations}

\begin{tabular}{|c|c|}
\hline AEC & U.S. Atomic Energy Commission \\
\hline bgs & Below ground surface \\
\hline $\mathrm{BN}$ & Bechtel Nevada \\
\hline CADD & Corrective Action Decision Document \\
\hline CAIP & Corrective Action Investigation Plan \\
\hline CAS & Corrective Action Site(s) \\
\hline $\mathrm{CAU}$ & Corrective Action Unit(s) \\
\hline CFR & Code of Federal Regulations \\
\hline $\mathrm{cm}$ & Centimeter(s) \\
\hline $\mathrm{COPC}$ & Contaminant(s) of potential concern \\
\hline DDD & Dichlorodiphenyldichloroethane \\
\hline $\mathrm{DDE}$ & Dichlorodiphenyldichloroethylene \\
\hline DDT & Dichlorodiphenyltrichloroethylene \\
\hline DOE & U.S. Department of Energy \\
\hline $\mathrm{DOE} / \mathrm{NV}$ & U.S. Department of Energy, Nevada Operations Office \\
\hline DOT & U.S. Department of Transportation \\
\hline DQO & Data Quality Objective(s) \\
\hline EPA & U.S. Environmental Protection Agency \\
\hline ERD & Environmental Restoration Division \\
\hline FFACO & Federal Facility Agreement and Consent Order \\
\hline $\mathrm{ft}$ & Foot (feet) \\
\hline $\mathrm{ft}^{3} / \mathrm{s}$ & Cubic feet per second \\
\hline HASP & Health and Safety Plan \\
\hline HWAA & Hazardous Waste Accumulation Area \\
\hline IDW & Investigation-derived waste \\
\hline in. & $\operatorname{Inch}(e s)$ \\
\hline IT & International Technology Corporation \\
\hline $\mathrm{m}$ & Meter(s) \\
\hline
\end{tabular}




\section{List of Acronyms and Abbreviations (Continued)}

\begin{tabular}{|c|c|}
\hline $\mathrm{m}^{3} / \mathrm{s}$ & Cubic meter(s) per second \\
\hline $\mathrm{mg} / \mathrm{kg}$ & Milligram(s) per kilogram \\
\hline $\mathrm{mg} / \mathrm{L}$ & Milligram(s) per liter \\
\hline$\mu \mathrm{g} / \mathrm{L}$ & Micrograms per liter \\
\hline MSDS & Material Safety Data Sheet \\
\hline NAC & Nevada Administrative Code \\
\hline NDEP & Nevada Division of Environmental Protection \\
\hline NEPA & National Environmental Policy Act \\
\hline NTS & Nevada Test Site \\
\hline NTSWAC & Nevada Test Site Waste Acceptance Criteria \\
\hline PAL & Preliminary Action Level(s) \\
\hline PCB & Polychlorinated biphenyl(s) \\
\hline $\mathrm{ppb}$ & Part(s) per billion \\
\hline ppm & Part(s) per million \\
\hline Q800 & Area 23 Quonset Hut 800 \\
\hline Q15-11 & Area 15 EPA Farm Quonset Hut 15-11, Pesticide Storage Area \\
\hline $\mathrm{QA} / \mathrm{QC}$ & Quality assurance and quality control \\
\hline QAPP & Quality Assurance Project Plan \\
\hline RCRA & Resource Conservation and Recovery Act \\
\hline $\mathrm{SAA}$ & Satellite Accumulation Area \\
\hline SVOC & Semivolatile organic compound(s) \\
\hline $\mathrm{TC}$ & Toxicity characteristic \\
\hline TCLP & Toxicity Characteristic Leaching Procedure \\
\hline TPH & Total petroleum hydrocarbon(s) \\
\hline VOC & Volatile organic compound(s) \\
\hline
\end{tabular}




\section{Executive Summary}

The Corrective Action Investigation Plan (CAIP) for Corrective Action Unit (CAU) 340, Pesticide Release Sites, at the Nevada Test Site (NTS) has been developed in accordance with the Federal Facility Agreement and Consent Order (FFACO) that was agreed to by the U.S. Department of Energy, Nevada Operations Office (DOE/NV); the State of Nevada Division of Environmental Protection (NDEP); and the U.S. Department of Defense. Corrective Action Unit 340 consists of the following three Corrective Action Sites (CAS):

- CAS 23-21-01, Area 23 Quonset Hut 800 Pesticide Release Ditch

- CAS 23-18-03, Area 23 Skid Huts Pesticide Storage

- CAS 15-18-02, Area 15 Quonset Hut 15-11 Pesticide Storage

The CAU was originally identified in the FFACO as having only a single CAS, the Quonset Hut 800 site. However, during the Data Quality Objectives process for the CAU, other sites were identified for possible inclusion into the CAU based on similar historical use and the release of pesticides and herbicides. Preliminary sampling at these sites indicated their presence. Therefore, as a logical and cost-effective approach, the Area 23 Skid Hut and the Area 15 Quonset Hut 15-11 sites were proposed by DOE/NV for inclusion into CAU 340 at the FFACO quarterly meeting in November 1997. The inclusion of these sites was approved by the NDEP on December 1, 1997.

At Area 23 Quonset Hut 800, contaminants of potential concern (COPCs) were released through pesticide and herbicide container rinsing practices associated with a nearby steam-cleaning pad. Rinsate was contained in a solids/oil separator; however, overflow from the separator resulted in release to a ditch at the site. The Area 23 Skid Huts were used for pesticide and herbicide storage and container rinsing, resulting in release of COPCs from spills and from disposal of rinsate. The Area 15 Quonset Hut 15-11 was historically used for pesticide and herbicide storage; COPCs were likely released through spills. The COPCs consist mainly of pesticides and herbicides with potential for other volatile organic compounds, semivolatile organic compounds, and petroleum hydrocarbon products that may have been components of or additives to the pesticides and herbicides. 
To support the Data Quality Objectives process, conceptual site models for the CASs were developed. The following general model elements apply to all three sites:

- The future uses of the area will probably be similar to current uses.

- Groundwater impacts are not expected because of the large depth to groundwater (Section 2.1).

- Environmental conditions at the site are not conducive to significant downward migration of COPCs (i.e., arid climate, high evaporation rates, soil type, and generally low permeabilities).

- The extent of COPCs is localized, and vertical and lateral migration is not significant.

- The most likely exposure pathway is inhalation of dust containing COPCs from excavation activities by site workers (e.g., heavy equipment, shovels, drilling).

Site-specific conceptual models for the individual CASs are presented in Section 3.0 of the CAIP. The sampling investigations are designed to test each of the conceptual models; contingencies or rescoping points are identified for site-specific or contaminant-specific conditions that fall outside the general model.

The sampling approach consists of a two-staged investigation. The first stage is designed to evaluate the nature and extent of COPCs throughout the investigation area on a wide scale and at expected worst-case locations. Samples collected for laboratory analysis during the first stage will be analyzed for a broad suite of parameters. The second stage will be scoped based on the results of Stage I sampling. For example, sampling depth, parameters, and sampling methods may be reduced or expanded in Stage II as justified by Stage I results.

Field-screening methods will be used to detect volatile organic compounds, semivolatile compounds, total petroleum hydrocarbons, and some pesticides in soil samples. Radiological surveys will also be conducted at each investigation site.

All wastes generated during this investigation will be managed under applicable federal, state, and local regulations and requirements. Details of the waste management plan for the CAU are included in Section 5.0 of the CAIP. Investigation-derived waste soil will be containerized and managed within the investigation area until a final waste determination can be made. 
Under the FFACO, the CAIP will be submitted to the Nevada Division of Environmental Protection by March 31, 1998. The field investigation will be conducted following NDEP approval of the CAIP, and the results of the field investigation will be used to support an evaluation of corrective action alternatives in the Corrective Action Decision Document. 


\subsection{Introduction}

This Correction Action Investigation Plan (CAIP) has been developed in accordance with the Federal Facility Agreement and Consent Order (FFACO) that was agreed to by the U.S. Department of Energy, Nevada Operations Office (DOE/NV); the State of Nevada Division of Environmental Protection (NDEP); and the U.S. Department of Defense. As required by the FFACO (1996), this document provides or references all of the specific information for planning investigation activities associated with three Corrective Action Sites (CASs) located at the Nevada Test Site (NTS) (Figure 1-1). These CASs are collectively known as Corrective Action Unit (CAU) 340, Pesticide Release Sites. According to the FFACO, CASs are sites that may require corrective action(s) and may include solid waste management units or individual disposal or release sites. These sites are CAS 23-21-01, Area 23 Quonset Hut 800 (Q800) Pesticide Release Ditch; CAS 23-18-03, Area 23 Skid Huts Pesticide Storage; and CAS 15-18-02, Area 15 Quonset Hut 15-11 Pesticide Storage (Q15-11) (Figure 1-2).

\subsection{Purpose}

The purpose of this CAIP for CAU 340 is to direct and guide the investigation for the evaluation of the nature and extent of pesticides, herbicides, and other contaminants of potential concern (COPCs) that were stored, mixed, and/or disposed of at each of the CASs.

The CAU was originally identified in the FFACO as having only a single CAS, the Quonset Hut 800 site. However, during the Data Quality Objectives (DQO) Process for the CAU, other sites were identified for possible inclusion into the $\mathrm{CAU}$ based on similar historical use and release of pesticides and herbicides. Preliminary sampling at these sites indicated the presence of pesticides and/or herbicides. Therefore, as a logical and cost-effective approach, the Area 23 Skid Huts site and the Area 15 Quonset Hut 15-11 were proposed by DOE/NV for formal inclusion in CAU 340 at the November 1997 FFACO quarterly meeting. This proposal was agreed to and approved by the NDEP December 1, 1997 (Liebendorfer, 1997).

This CAIP was developed using the U.S. Environmental Protection Agency (EPA) DQO process to clearly define the objectives for the CAS investigations (EPA, 1994). The DQO process aids in the 


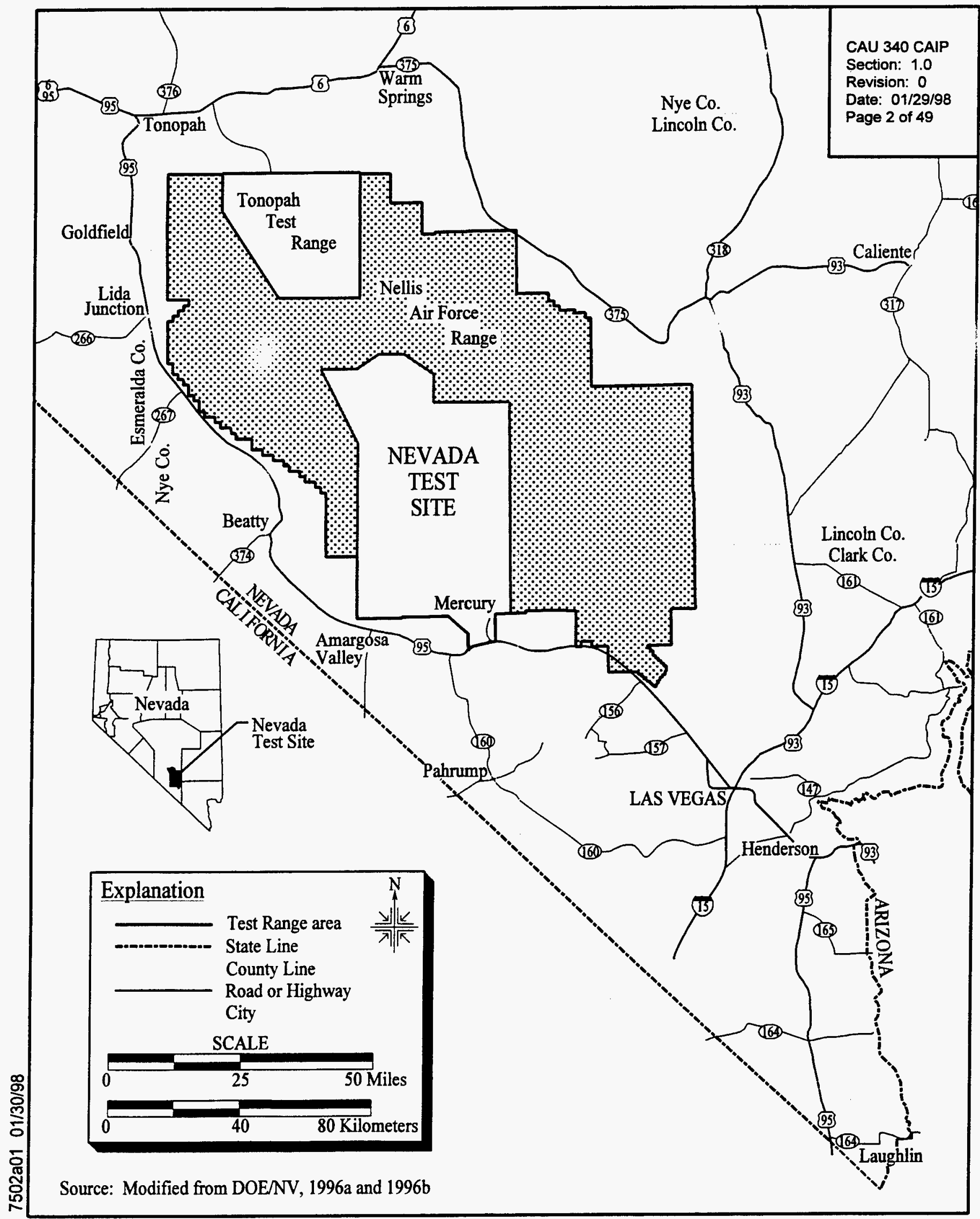

Figure 1-1

Location of the Nevada Test Site, Nye County, Nevada 


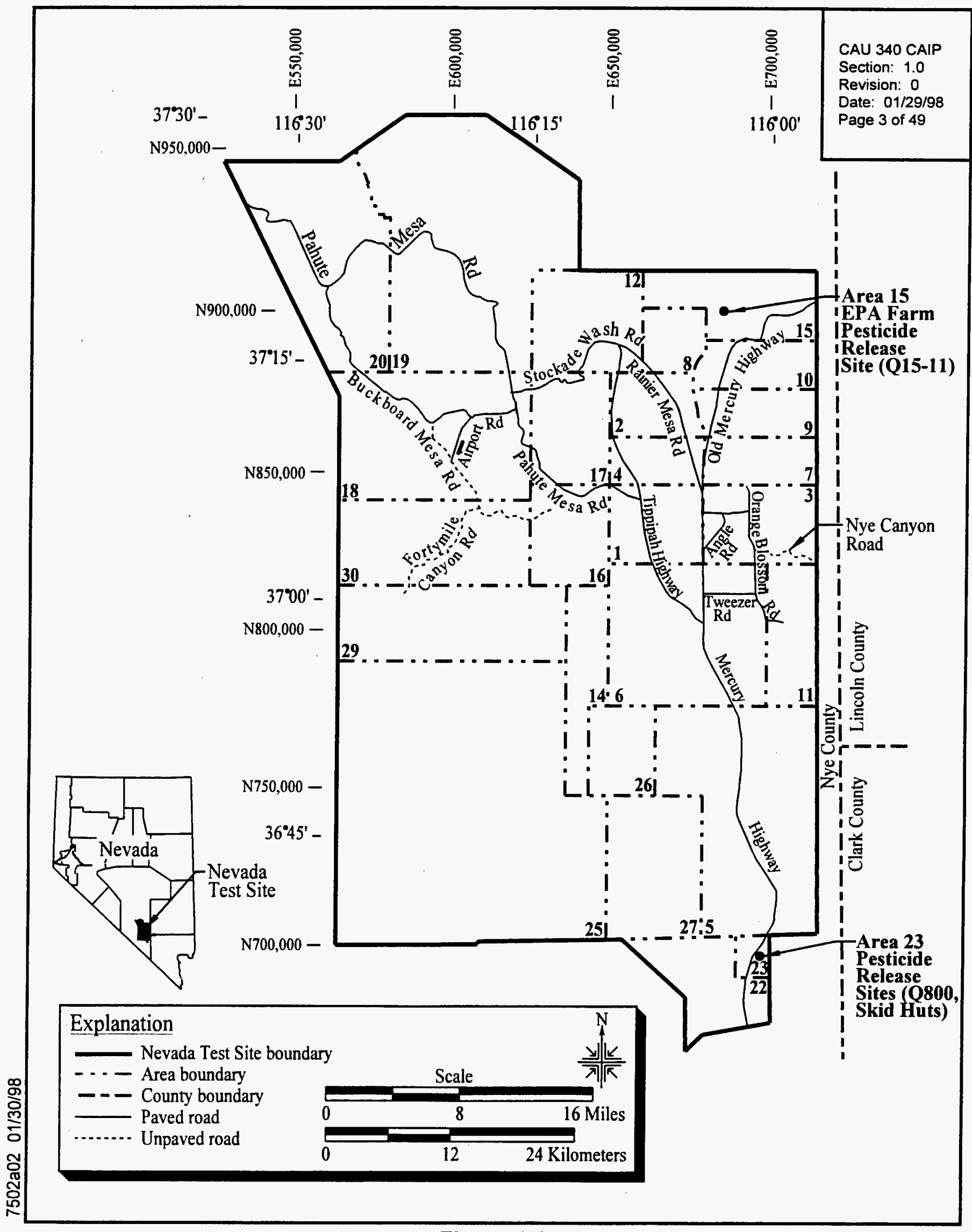

Figure 1-2

General Location of the Area 23 and Area 15 Pesticide Release Sites 
development of investigative decisions and inputs to ensure data will be of sufficient quality and quantity to support defensible corrective action decisions. At the same time, the investigation developed should reduce data collection costs by eliminating unnecessary, duplicative, or overly precise data (FFACO, 1996). The results of the DQO process are presented in Appendix A and include the DQO methodology and its application to this plan.

\subsection{Scope}

The scope of this CAIP is to describe the overall investigation strategy, sampling and analytical methods, and data needs that will be used to guide the CAS investigations. The investigations will include the collection of soil samples and evaluation of the analytical data to identify the nature and extent of COPCs and resolve the DQO problem statement (i.e., insufficient data exist to make corrective action decision[s] for the CASs).

\subsection{CAIP Contents}

This section provides a matrix of FFACO requirements and indicates where these requirements are met in the CAIP or in other available documents (Table 1-1) (FFACO, 1996). 
Table 1-1

References and Supporting Documentation for the Corrective Action Investigation Plan for CAU 340 by Topic

\begin{tabular}{|c|c|}
\hline Topic & Reference to CAIP Section or Document \\
\hline \multirow[t]{2}{*}{ Project Management } & $\begin{array}{l}\text { Project Management Plan. Rev. O. Environmental Restoration } \\
\text { Project (DOE/NV, 1994a) }\end{array}$ \\
\hline & Investigation Duration - Section 6.0 \\
\hline Technical Aspects & CAIP - Sections 3.0, 4.0, and Appendix A \\
\hline \multirow[t]{2}{*}{ Quality Assurance/Quality Control } & $\begin{array}{l}\text { Industrial Sites Quality Assurance Project Plan (DOE/NV, } \\
\text { 1996d) (QAPP) }\end{array}$ \\
\hline & $\begin{array}{l}\text { Standard Operating Procedures Manual, (DOE/NV, 1994c, } \\
\text { as amended) }\end{array}$ \\
\hline \multirow[t]{2}{*}{ Health and Safety } & $\begin{array}{l}\text { Health and Safety Plan. Environmental Restoration Project } \\
\text { (DOE/NV, 1996b, Rev. 2) (HASP) }\end{array}$ \\
\hline & $\begin{array}{l}\text { Site-Specific Health and Safety Plan (to be prepared prior to } \\
\text { field activities) }\end{array}$ \\
\hline Public Involvement & $\begin{array}{l}\text { Public Involvement Plan, Appendix V, FFACO } \\
\text { (none specifically planned for this CAIP) (FFACO, 1996) }\end{array}$ \\
\hline Field Sampling & CAIP - Section 4.0 \\
\hline Waste Management & CAIP - Section 5.0 \\
\hline Duration of Investigation & CAIP - Section 6.0 \\
\hline
\end{tabular}




\subsection{Facility Description}

The NTS is a U.S. Department of Energy (DOE) research and development facility that has historically been associated with above-and below ground nuclear weapons testing. Corrective Action Unit 340 is located at the NTS, which is about 88 kilometers (55 miles) northwest of Las Vegas, Nevada.

\subsection{Physical Setting}

The following provides the CAS locations, description of the investigation areas, and general physical and ambient aspects of each site.

\subsubsection{Location and Description of the Investigation Area(s)}

The Q800 and Skid Huts are located in Area 23, the southern part of the NTS, while Q15-11 is located in Area 15, the northern part of the NTS (Figure 1-2).

The investigation area for CAS Q800 (Figure 2-1) includes the entire length of the ditch that extends from the edge of the solids/oil separator southward approximately 150 meters (m) ( 500 feet [ft]) to an intersecting flood control channel. The separator is not included in the investigation area and will remain with building Q800 until decommissioning. The clay discharge pipe associated with the solids/oil separator and the metal drainage pipe where it exits the Q800 building to its terminus at the ditch will be managed and disposed of at the conclusion of the investigation.

The Skid Huts investigation area is immediately east of the Q800 investigation area (Figure 2-2). The Skid Huts investigation area includes the immediate area surrounding the historic footprint of the three skid huts (Figure 2-3), including the hose bibb ( $\sim 12 \mathrm{~m}[40 \mathrm{ft}]$ by $18 \mathrm{~m}[60 \mathrm{ft}]$ ). The Skid Huts investigation area is bounded on the east by an abandoned sewage treatment plant and on the south by a channel that conveyed treated effluent from the plant to sewage lagoons (the sewage lagoons are not shown).

The Q15-11 investigation area (Figure 2-4) is limited to the footprint of the Q15-11 building and the elevated area on the south end of the building (i.e., the area with a metal grate that was used for loading/unloading supplies and/or parking). 


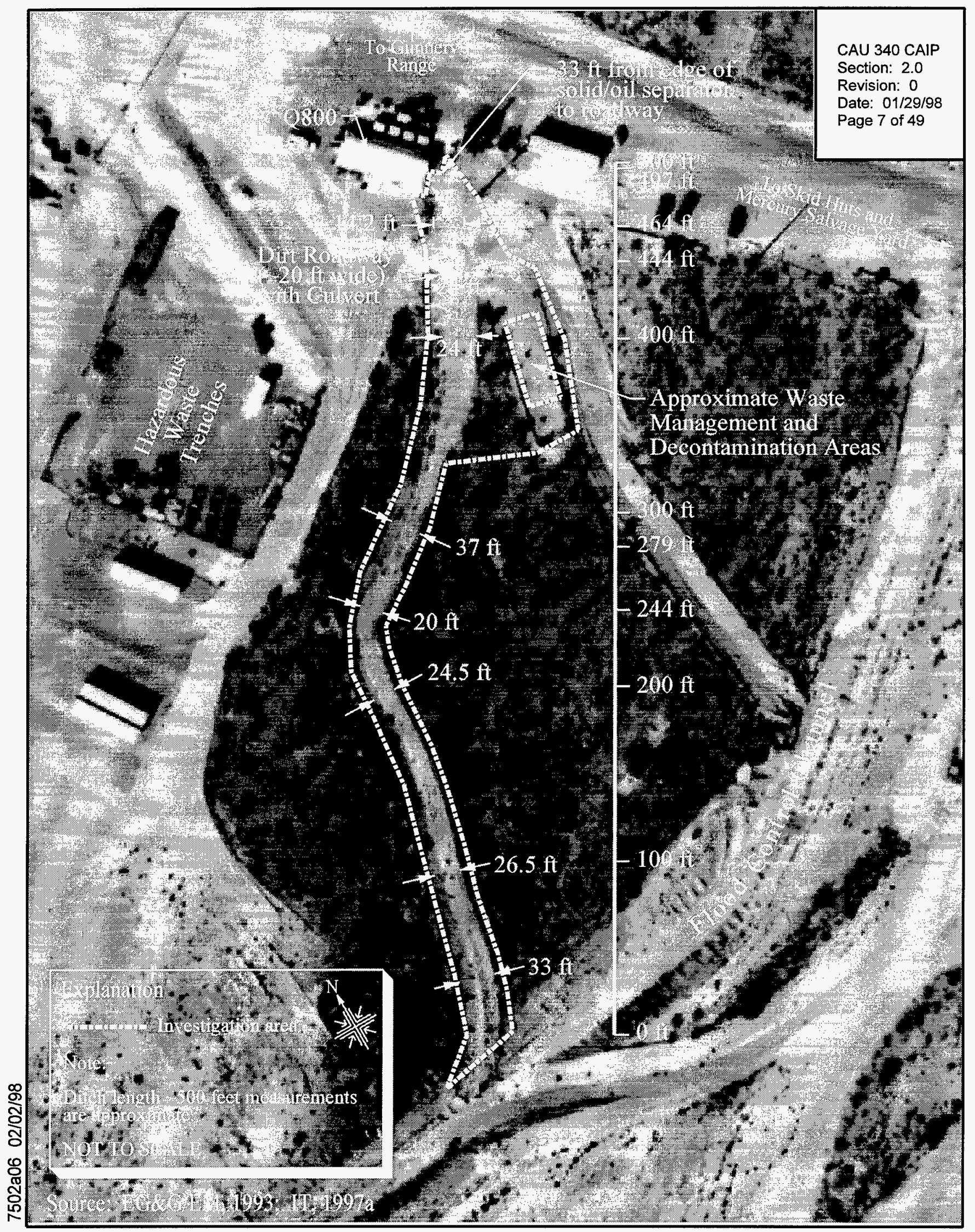

Figure 2-1

General Layout of the Area 23 Quonset Hut 800 Investigation Area 


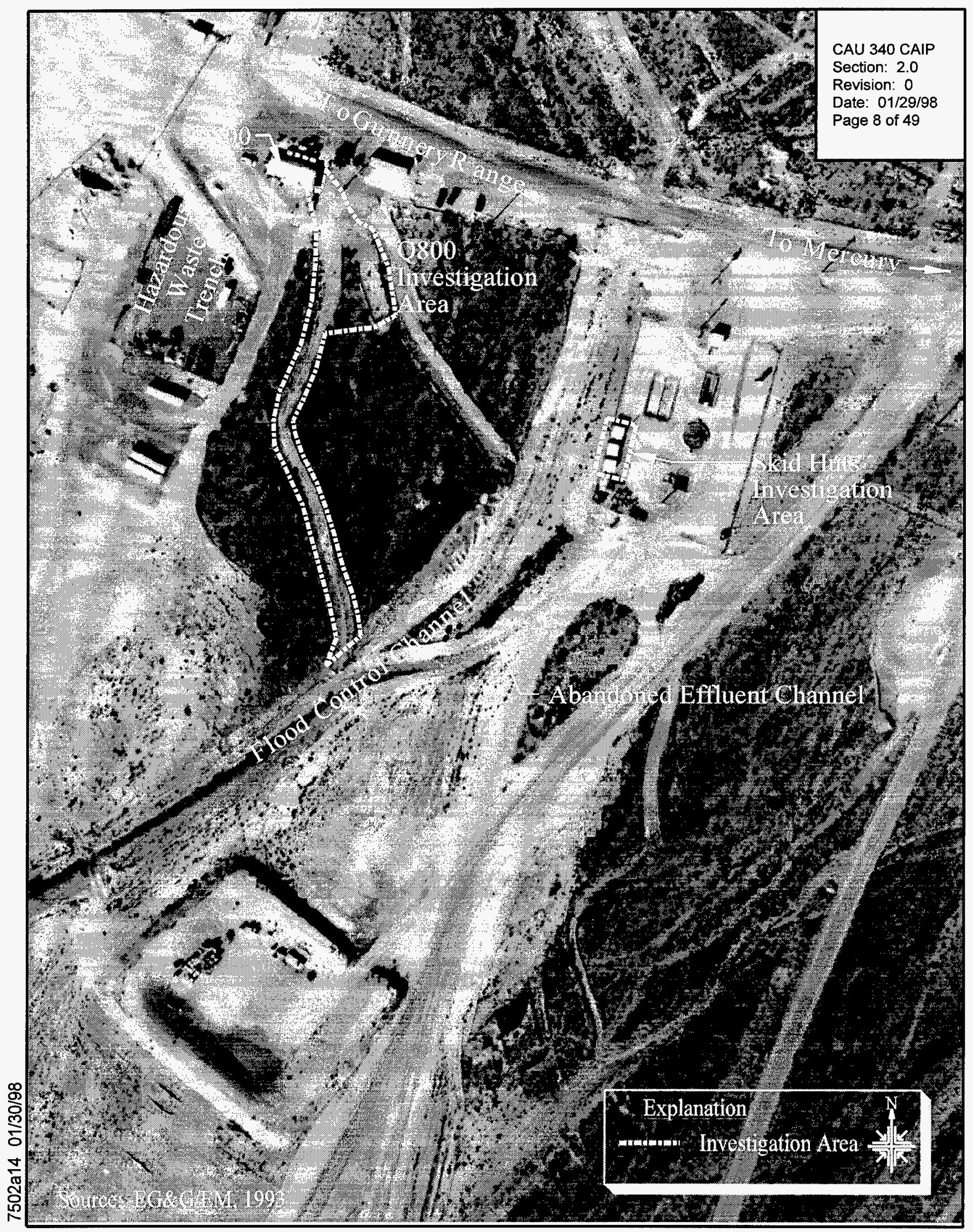

Figure 2-2

Location of the Area 23 Quonset Hut 800 and Skid Huts Investigation Areas 


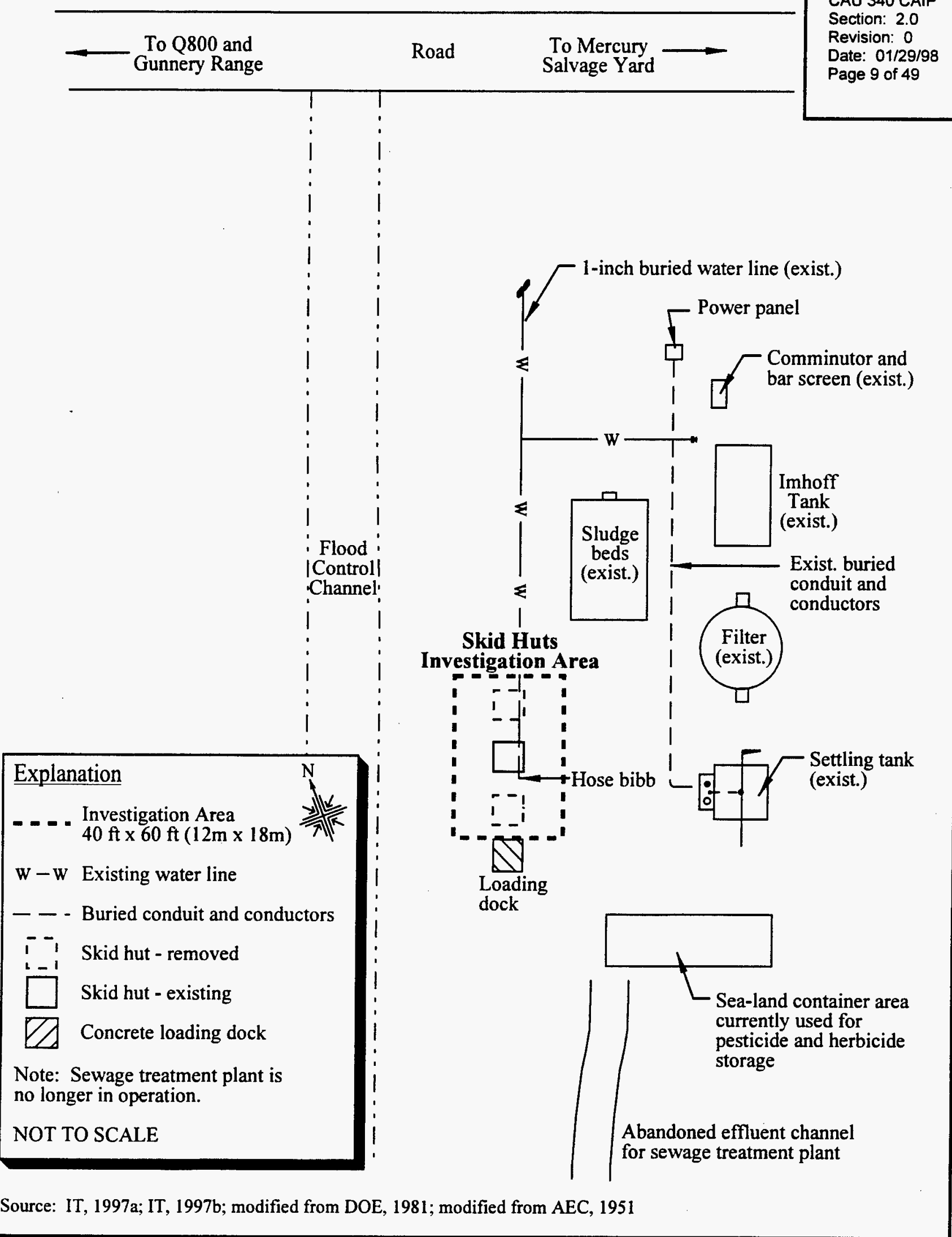

Figure 2-3

General Layout of the Area 23 Skid Huts Investigation Area 


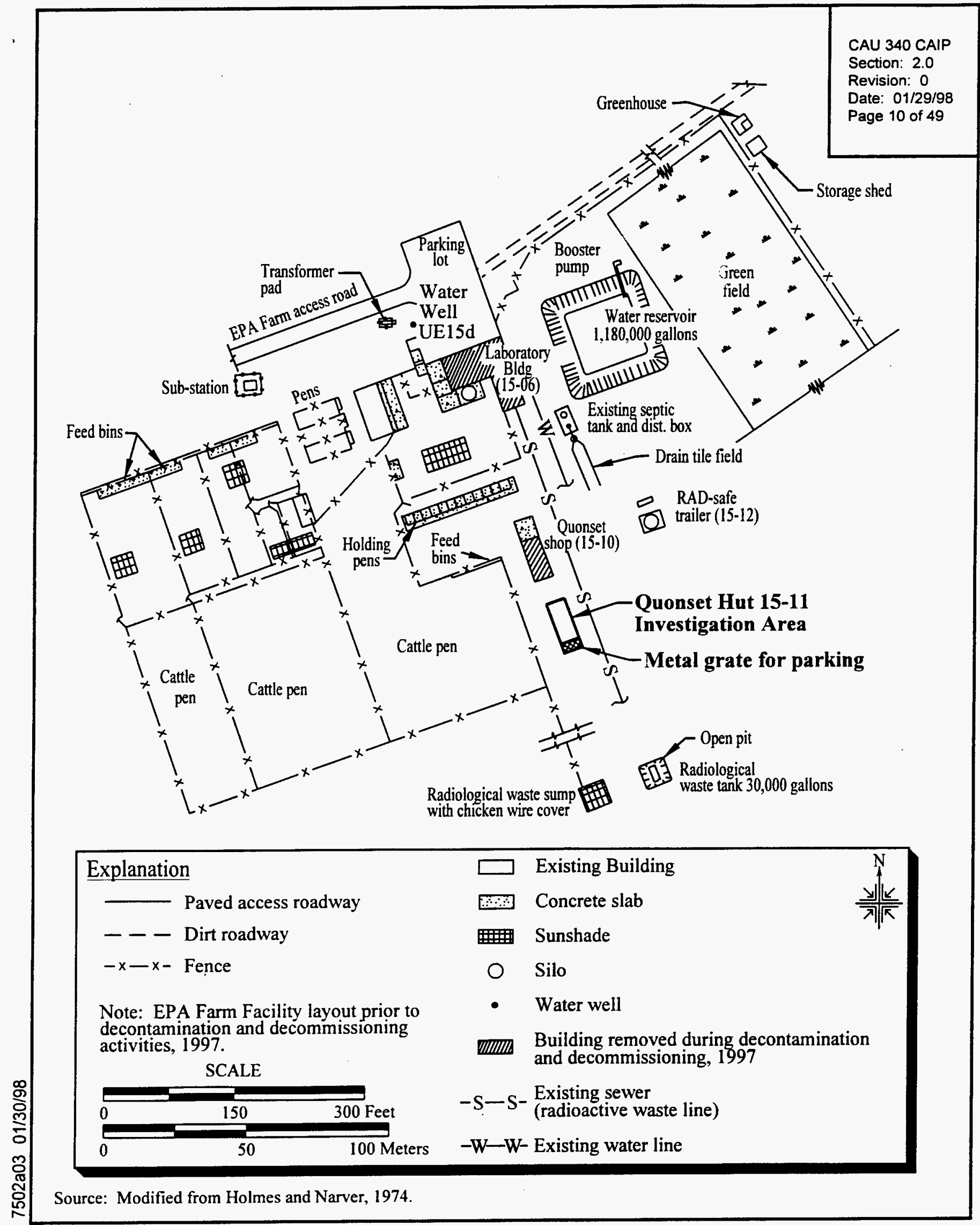

Figure 2-4

General Layout of the Area 15 Quonset Hut 15-11 Investigation Area 
Included within each of the investigation areas are controlled zones used for decontamination and waste management purposes. The exact size and location of these controlled zones will be specified prior to investigation. The CAS investigation areas will be fenced to control and prevent desert tortoises and any unauthorized foot and vehicle traffic from entering the areas.

\subsubsection{Topography}

The Area 23 Q800 and Skid Huts CASs (Figure 2-2) are located on an alluvial fan that slopes southwest from Red Mountain (carbonate rock) toward Mercury Valley. The elevation at these sites is approximately $1,110 \mathrm{~m}$ (3,640 ft ) above sea level (USGS, 1983a; USGS, 1983b).

The Area 15 Q15-11 CAS (Figure 2-4) is located at an elevation of $1,390 \mathrm{~m}(4,570 \mathrm{ft})$ on coalescing alluvial fans that grade about 3.0 percent toward the southeast (USGS, 1986b; Holmes and Narver, 1971; Holmes and Narver, 1974). The alluvial fans are bordered on the west by Quartzite Ridge and the Smoky Hills, on the north by Oak Spring Butte, and on the east by the Rhyolite Hills (USGS, 1986a; USGS, 1986b).

\subsubsection{Groundwater}

The groundwater is not expected to be impacted by COPC migration from any of the pesticide sites because of the relative immobility of the COPCs (e.g., pesticides) and the depth to the water. In the Mercury Valley (Area 23 sites) the depth to groundwater is approximately $240 \mathrm{~m}$ to $340 \mathrm{~m}$ ( $800 \mathrm{ft}$ to 1,100 ft) (Winograd and Thordarson, 1975; Robie et al., 1995) while the static water level in the UE-15d (Figure 2-4) water well at the EPA Farm is approximately $204 \mathrm{~m}$ (668 ft) below ground surface (bgs) (USGS, 1973). Located in the area northeast of Q15-11 is a leachfield (drain tile field), and immediately east is a sewage line that drained effluent to the radioactive sump from the EPA Laboratory Building 15-06 (Figure 2-4). However, no impacts to site investigations are expected from the leach field or from possible leakage of the sewage line because of the expected near-surface extent of COPCs.

\subsubsection{Surface Water}

There are no perennial surface water sources that occur in Area 23 that would impact the investigation areas. However, Bechtel Nevada (BN) conducted a limited flood assessment for the 
Area 23 Hazardous Waste Trenches (CAU 112) and sewage lagoons for closure purposes (BN, 1996). The Q800 and the Skid Huts CASs are immediately adjacent to the hazardous waste trenches (Figure 2-2). The site-specific field investigations included measurements of channel geometry, channel roughness, and surficial deposit information. The hazardous waste trenches and sewage lagoons were found not to be within the 100-year flood hazard zone. The natural ephemeral drainage has been significantly modified from its natural state because of grading and berming associated with landfill activities, construction (i.e., roads, gunnery range), and channel modification. Channels on either side of the gunnery range were examined for the ability to contain the calculated peak discharge of about 8.64 cubic meters per second $\left(\mathrm{m}^{3} / \mathrm{s}\right)\left(305\right.$ cubic feet per sec ond $\left.\left[\mathrm{ft}^{3} / \mathrm{s}\right]\right)$ because the diversion created by the gunnery range berms could divert the entire flow either to the west or the east (BN, 1996). Channel modifications (i.e., widening or deepening) were made as necessary to accommodate the peak discharge flow $(\mathrm{BN}, 1996)$. Flow at the Q800 ditch is possible if localized run-on occurs. No flows are expected to impact the majority of the Skid Huts except in the event of flash flooding, where the western boundary near the flood control channel could be impacted (Figure 2-2 and Figure 2-3).

No impacts to the Q15-11 investigation area are expected from perennial surface water sources or ephemeral drainage channels. The Q15-11 building is still present and protects the site from natural precipitation (e.g., rain or snow). Potential surface run-on from animal holding pens or drainages from historic EPA Farm facility operations are not expected to have impacted the investigation site.

\subsubsection{Geology}

The near-surface alluvium in Area 23 is composed of silty sands containing abundant gravel and cobbles. Some boulders, up to $1.0 \mathrm{~m}(\sim 3 \mathrm{ft})$ in diameter, have been noted (DOE/NV, 1997). Caliche was observed in the boreholes drilled at the adjacent hazardous waste trenches (REECo, 1993a; REECo, 1993b; DOE/NV, 1997); therefore, localized caliche could be present at the Area 23 sites. Geological concerns for this site would include the possible occurrence of caliche at approximately $3 \mathrm{~m}(\sim 10 \mathrm{ft})$ below ground surface. If caliche is encountered, operations could be slowed significantly because of its potential to be extremely hard. If present, caliche may provide a significant barrier to any potential downward migration of COPCs. 
The soil in the EPA Farm area is a coarse, sandy loam which could be conducive to infiltration if a sufficient driving force at Q15-11 was present (EPA, 1978). However, no sinks or drains are present, and meteorological precipitation is not expected to be a factor because the area is covered. COPCs are expected to be limited to the investigation area.

\subsection{Operational History}

The operational history for CAU 340 has been inferred from various sources and the best available information. Much of the information is from interviews with current and former employees, Material Safety Data Sheets (MSDSs) and product information (when available), aerial photographs, engineer drawings, and various NTS reports (IT, 1997a). Reasonable and practical attempts have been made to gain useful and precise knowledge of operations associated with these sites.

\subsubsection{CAS 23-21-01 Area 23 Quonset Hut 800}

Generally, the operations that have impacted the environment associated with Q800 include the discharge of excess pesticide and herbicide rinsate to a drainage ditch (IT, 1997b). The rinsate from steam-cleaning operations drained to a solids/oil separator. The separator was periodically pumped out; however, it occasionally overflowed through a clay pipe to the Q800 ditch (Figure 2-1). In addition to steam-cleaning rinsate, drainage from two sinks and a washer inside Q800 also discharged pesticide/herbicide rinsate and greywater to the ditch (Bielawski, 1993; REECo, 1993c; Taylor, 1994). The time period of pesticide and herbicide disposal and the quantities discharged are unknown. However, Q800 has been in existence since 1952 (IT, 1997a).

Both the steam-cleaning operations and the sink drainage resulted in release of pesticides, herbicides, and other COPCs to the soil in the ditch. The clay pipe was sealed (grouted), and water to the sinks inside of the building was turned off in the early 1990s. The building remains in that condition (REECo, 1993c; Taylor, 1994). Steam-cleaning operations are currently ongoing, and the rinsate is contained in a large, open metal tank that has been placed on the steam-cleaning pad.

\subsubsection{CAS 23-18-03 Area 23 Skid Huts}

The Skid Huts site was used for pesticide and herbicide storage and mixing. Excess pesticide and herbicide solutions and rinsate were disposed of directly to the ground near the Skid Huts (IT, 1997a). 
Skid Huts were present at the site by 1968 , but the period of use for pesticide and herbicide storage is uncertain (IT, 1997a). By 1983, all pesticides and herbicides at the NTS were consolidated at these three Skid Huts (IT, 1997a) (Figure 2-3). The disposal of excess pesticide and herbicide solution or rinsate to the ground also ceased at that time (IT, 1997a).

\subsubsection{CAS 15-18-02 Area 15 EPA Farm Quonset Hut 15-11}

The Q15-11 at EPA Farm (Figure 2-4) was used for the routine storage of farm supplies, light equipment, pesticides, herbicides, and fertilizers from the late 1960 s to early 1980 s (IT, 1997a). The EPA Farm reports document the types of pesticides and herbicides used and the quantities that were applied to irrigated areas (EPA, 1978; EPA, 1980). However, the amount of product stored at any given time in Q15-11 is unknown. The EPA Farm operations were closed in 1981. In 1983, all pesticides and herbicides at the NTS were consolidated at the Area 23 Skid Huts (IT, 1997a). At that time, it was noted that only a few aerosol cans of roach spray were moved from Q15-11 to the Skid Huts (IT, 1997a). The extent of COPCs at Q15-11 is expected to be localized to stained areas. There is no evidence of any sinks, pipes, drains, or water sources at Q15-11 that would aid in the migration of COPCs from the area.

\subsection{Waste Inventory}

Typically, both restricted and nonrestricted pesticides and herbicides were used at the NTS. Restricted pesticides (e.g., dichlorodiphenyltrichloroethylene [DDT], chlordane) were used at the NTS during the period when their use was common in the United States (IT, 1997a). Preliminary analytical results for the Q800 site (see Section 2.5.1 for more detail) indicate the presence of several pesticides including DDT, dichlorodiphenyldichloroethylene (DDE), dichlorodiphenyldichloroethane (DDD), and chlordane in the Q800 ditch (Neagle, 1994). Few records (e.g., MSDS, purchase orders) were found that could provide specific pesticide or herbicide information on additional types or quantities used or stored.

Specific details concerning the exact types and amounts of products stored in the Skid Huts are limited. During the time period from 1983 to 1994 , typically a 4 to 5 months supply of product was stored at the Skid Huts (IT, 1997b). 
In general, pesticides used at the EPA Farm for fly abatement included products such as pyrethrins, Vapona (2,2 dichlorovinyldimethyl phosphate), Kemal (toxaphene and malathion), Diazinon AG500, and Rabon (2-chloro-1-[2,4 5-trichlorophenyl] vinyldimethylphosphate). Malathion (56.5\%) was used to control aphid infestations. Herbicides include Ureabor (sodium metaborate tetrahydrate, sodium chlorate, and bromacil), 2-4-D (2-4 dichlorophenoxy-acetic acid), Paraquat (dimethylbipyridyliumion), Hydrothol 191 (mono [n, n-dimethlyalkylamine] salt of 7-oxabicyclo $[2,2,1]$ heptane-2, 3-dicarboxlylic acid), and diesel oil. Fertilizers used included Treble superphosphate $\left(45 \% \mathrm{P}_{2} \mathrm{O}_{5}\right)$ and urea $(45 \%$ nitrogen). The actual amounts of product kept in storage at Q15-11 are not known (Douglas, 1967; Daley, 1968; EPA, 1978; EPA, 1980).

\subsection{Release Information}

There is no evidence to indicate the release or migration of any COPCs has occurred beyond the specified CAS investigation areas. At Q800, dispersal of COPCs could be associated with the grading of the ditch. The ditch was graded in the past to reduce nuisance odor from ponded water near Q800 (ITLV, 1997a). The graded soil was placed on both sides of the ditch banks and could contain COPCs. The investigation area (Figure 2-1) will include the mounds of soil on the ditch banks for the entire length of the Q800 ditch (150 $\mathrm{m}[\sim 500 \mathrm{ft}])$. If COPCs extend beyond the intersection of the ditch and the flood channel, these COPCs will be investigated under the CAU 444 Mercury Landfill. A roadway was constructed (late 1980s) across the ditch using clean fill soil from a nearby source (IT, 1997b), and a culvert was installed within the roadway to allow the ditch to drain. No COPCs are expected in the fill material. However, as a confirmation, the upstream part of the roadway near the culvert will be sampled and analyzed.

Any COPC dispersal from the Skid Huts site would most likely be from grading of soils in the area. During visual inspection of the site (IT, 1997a), staining was observed to the north and south of the existing Skid Huts (Figure 2-3). Historically, a sink in the hut drained toward the west (IT, 1997b). The sink drainage area and the stained area (north) of the hut appear to have been graded, and the redistributed soils may have contained COPCs. Typically, grading was conducted for roadway maintenance and for flood channel contouring immediately west of the site (Figure 2-2). There is no evidence to indicate that any significant release or redistribution of COPCs is expected to have 
occurred outside of the investigation area. If COPCs extend beyond the investigation area, then the existing sample plan needs to be reevaluated.

The COPCs associated with CAS Q15-11 (Figure 2-4) are expected to be of relatively minor extent and limited to surface and shallow subsurface soil under the quonset hut flooring. During visual inspection of Q15-11 on August 27, 1997, some staining of the plywood flooring and soil immediately under the flooring was observed (IT, 1997a). There is no evidence to indicate that COPCs have migrated beyond the investigation area. If COPCs extend beyond the investigation area, then rescoping will be necessary.

\subsection{Investigative Background}

Preliminary samples were collected and analyzed for each of the CASs. The rationale for sample collection and the preliminary results are discussed in the following text.

\subsubsection{CAS 23-21-01 Area 23 Quonset Hut 800}

On June 9, 1994, REECo collected soil samples from the Q800 ditch to support a potential sewage tank installation (no longer under consideration). There was concern that pesticides may be present in the ditch, and samples were collected for analyses (Neagle, 1994). Nine soil samples were collected from the outfall area to about $37 \mathrm{~m}(120 \mathrm{ft}$ ) downgradient along the ditch bottom (Figure 2-5), and at every $12-\mathrm{m}(40-\mathrm{ft})$ interval, three samples were composited into one sample. The samples were analyzed for total pesticides (EPA 8080/8141) (Neagle, 1994). The 1994 analytical results are summarized in Table 2-1. Sample results indicate the presence of several pesticides. Chlordane may be above the maximum concentration for the toxicity characteristic (TC) set forth in the Code of Federal Regulations (CFR), 40 CFR 261.24 (CFR, 1993; Neagle, 1994). Further characterization of this site is necessary before any determinations can be made with respect to TC levels (Neagle, 1994).

\subsubsection{CAS 23-18-03 Area 23 Skid Huts}

On August 27, 1997, three surface-soil samples were collected from stained areas at Area 23 Skid Huts location (Figure 2-6). The preliminary samples were analyzed for volatile organic compounds (VOCs); total petroleum hydrocarbons (TPH)-diesel and oil; semivolatile organic compounds (SVOCs); Resource Conservation and Recovery Act (RCRA) metals; total pesticides; total 


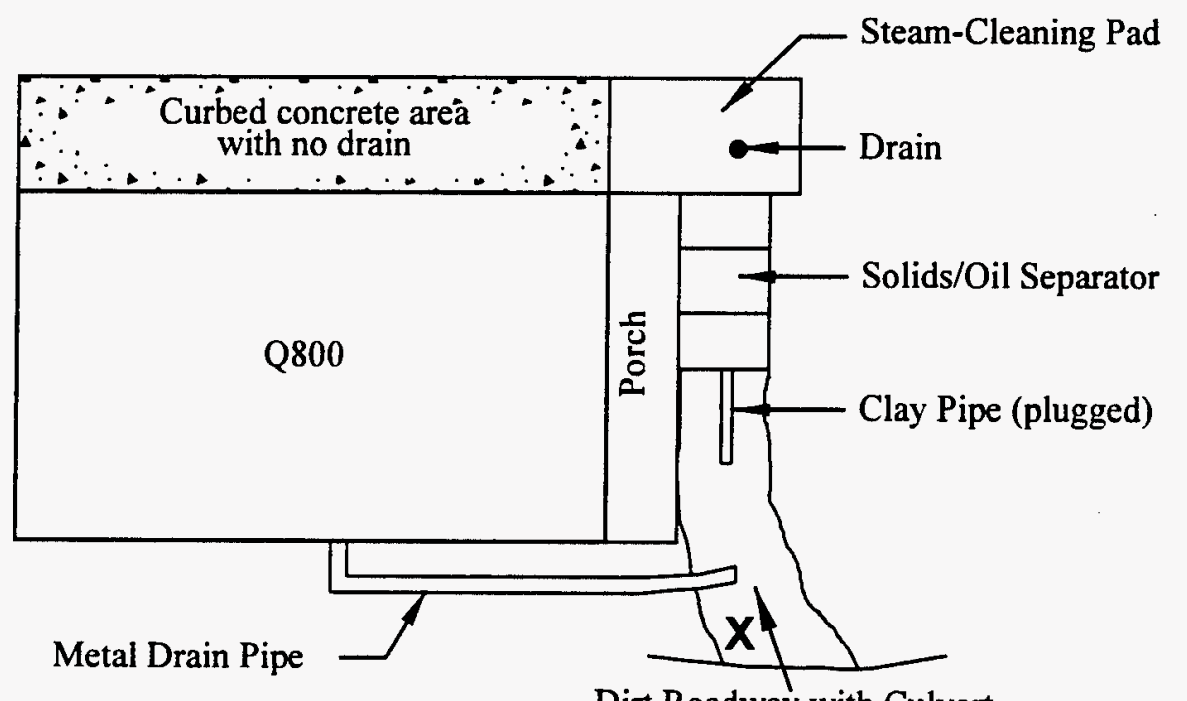

Dirt Roadway with Culvert

$\begin{array}{cc}\frac{\text { Explanation }}{\mathrm{X}} & \text { Sample locations } \\ & 40 \mathrm{ft} \text { intervals }\end{array}$

94BAH0609-1 Composite sample number

Note: Approximate locations for soil samples collected June 9, 1994, from Q800 ditch by Reynolds Electrical and Engineering Co., Inc. Samples were taken as composites from three, 40 -foot sections.

\section{NOT TO SCALE}
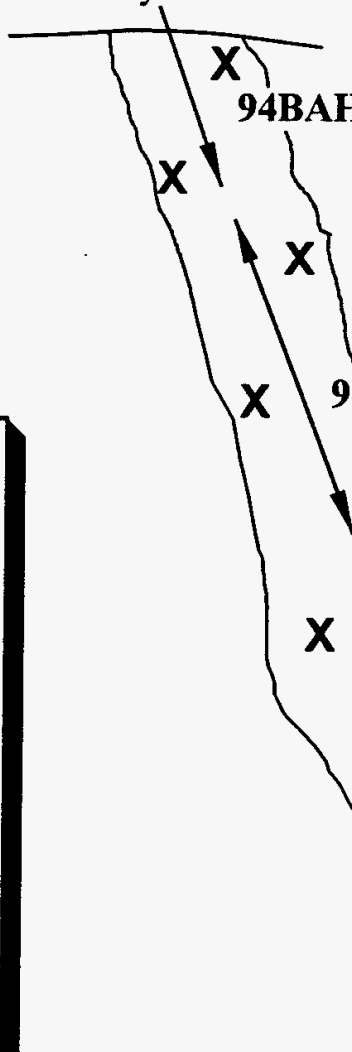

\section{BAH0609-1}
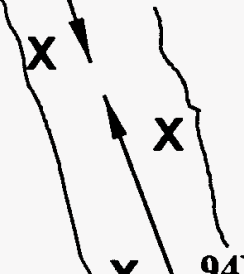

94BAH0609-2

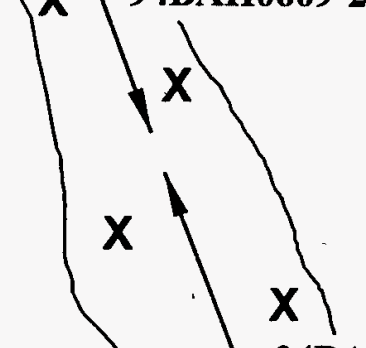

Source: Modified from Neagle, 1994

Figure 2-5 
Table 2-1

Area 23 Quonset Hut 800

Summary of the Preliminary Sampling Analytical Results for June 9, 1994, for Total Pesticides

\begin{tabular}{||l|c|c|c|}
\hline \multirow{2}{*}{ Pesticide } & \multicolumn{3}{|c|}{ Concentration by Sample (ppm) } \\
\cline { 2 - 4 } & 94BAH0609-1 & 94BAH0609-2 & 94BAH0609-3 \\
\hline \hline Chlordane & 33 & 120 & 57 \\
\hline $4,4^{\prime}-$ DDD & 1.5 & 80 & .63 \\
\hline $4,4^{\prime}-$ DDE & 2.2 & 13 & 1.8 \\
\hline $4,4^{\prime}-$ DDT & .49 & 320 & .33 \\
\hline Diazinon & 3.6 & ND & ND \\
\hline
\end{tabular}

ppm = Part(s) per million

ND $=$ Not detected

herbicides; and gamma spectroscopy. The analytical results are shown in Table 2-2. Further sampling is required for thorough investigation of $\mathrm{COPC}$ concentrations at this site.

\subsubsection{CAS 15-18-02 Area 15 EPA Farm Quonset Hut 15-11}

During a site visit to the EPA Farm, stained plywood and soil at Q15-11 were observed and suspected of possibly being contaminated with pesticides or herbicides (IT, 1997a). Subsequently, at the DQO discussions for the Q800 pesticide release site, it was suggested that Q15-11 be included in CAU 340. Surface-soil samples were collected at Q15-11 (Figure 2-7), and preliminary analyses obtained on October 1997 indicated the presence of pesticides. The pesticides detected are listed in Table 2-3.

\subsubsection{National Environmental Policy Act (NEPA) Requirements}

Site investigation activities associated with CAU 340 have been identified and documented in the Final Environmental Impact Statement for the Nevada Test Site and Off-Site Locations in the State of Nevada (DOE/NV, 1996a). 


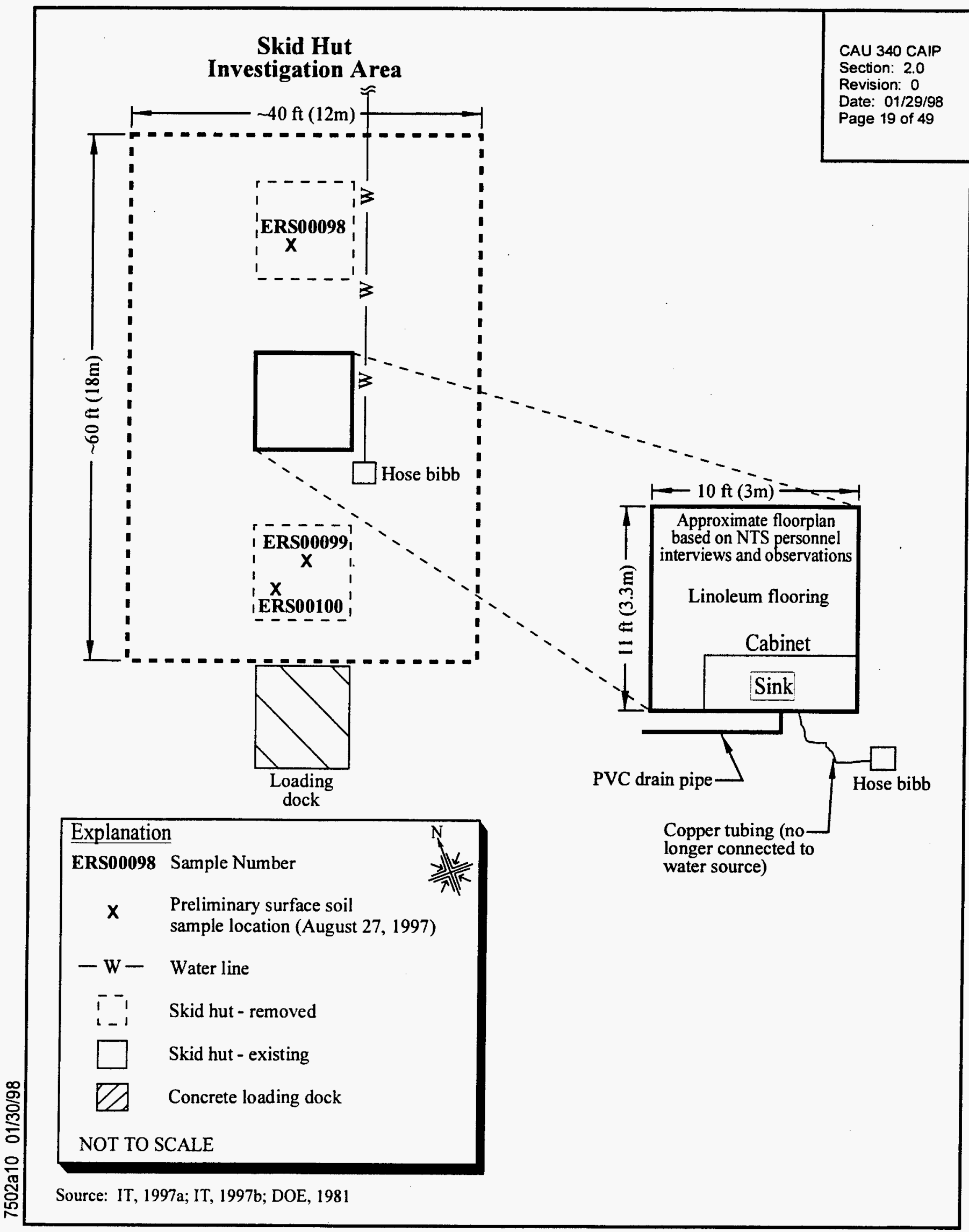


Table 2-2

Area 23 Skid Huts

Summary of Preliminary Sampling Analytical Results August 27, 1997 for Selected Parameters

\begin{tabular}{|c|c|c|c|}
\hline \multirow{2}{*}{ Parameter } & \multicolumn{3}{|c|}{ Concentration by Sample (ppm) } \\
\hline & ERS00098 & ERS00099 & ERS00100 \\
\hline \begin{tabular}{|l} 
Pesticides \\
4,4'-DDE \\
4,4'-DDD \\
4,4'-DDT \\
Endosulfan II \\
Endosulfan Sulfate
\end{tabular} & $\begin{array}{l}1.4 \\
3.4 \\
8.6 \\
0.86 \\
\text { ND }\end{array}$ & $\begin{array}{c}2.3 \\
5.0 \\
18.0 \\
1.2 \\
\text { ND }\end{array}$ & $\begin{array}{c}5.1 \\
2.8 \\
47.0 \\
\text { ND } \\
0.26\end{array}$ \\
\hline $\begin{array}{l}\text { Herbicides } \\
\text { MCPA }^{\circ} \\
\text { MCPP }^{\circ} \\
\text { Dichloroprop } \\
2,4,5-T^{c}\end{array}$ & $\begin{array}{c}38 \\
60 \\
0.11 \\
0.097\end{array}$ & $\begin{array}{l}\text { ND } \\
\text { ND } \\
\text { ND } \\
2.7\end{array}$ & $\begin{array}{c}15 \\
11 \\
\text { ND } \\
0.12\end{array}$ \\
\hline $\begin{array}{l}\text { RCRA Metals } \\
\text { Arsenic } \\
\text { Barium } \\
\text { Cadmium } \\
\text { Chromium } \\
\text { Lead }\end{array}$ & $\begin{array}{c}7.7 \\
84.4 \\
\text { ND } \\
7.1 \\
37.4\end{array}$ & $\begin{array}{c}5.3 \\
79.1 \\
\text { ND } \\
8.5 \\
30.6\end{array}$ & $\begin{array}{c}5.8 \\
81.7 \\
0.55 \\
13.2 \\
710\end{array}$ \\
\hline VOCs & NA & NA & NA \\
\hline $\begin{array}{l}\text { SVOCs } \\
\text { bis (2-Ethylhexyl) Phthalate }\end{array}$ & 1.7 & ND & ND \\
\hline TPH (diesel and oil) & ND & ND & ND \\
\hline Gamma Spectroscopy & background & background & background \\
\hline
\end{tabular}

a 2-methyl-4-chtorophenoxy aectic acid

$b_{2}$-(2-methyl-4-chlorophenoxy propionic acid

$c_{2,4,5}$ trichlorophenoxyaectic acid

VOCs = Volatile organic compounds

SVOCs = Semivolatile organic compounds

NA = Not available

ND $=$ Not detected

ppm = Parts per million 


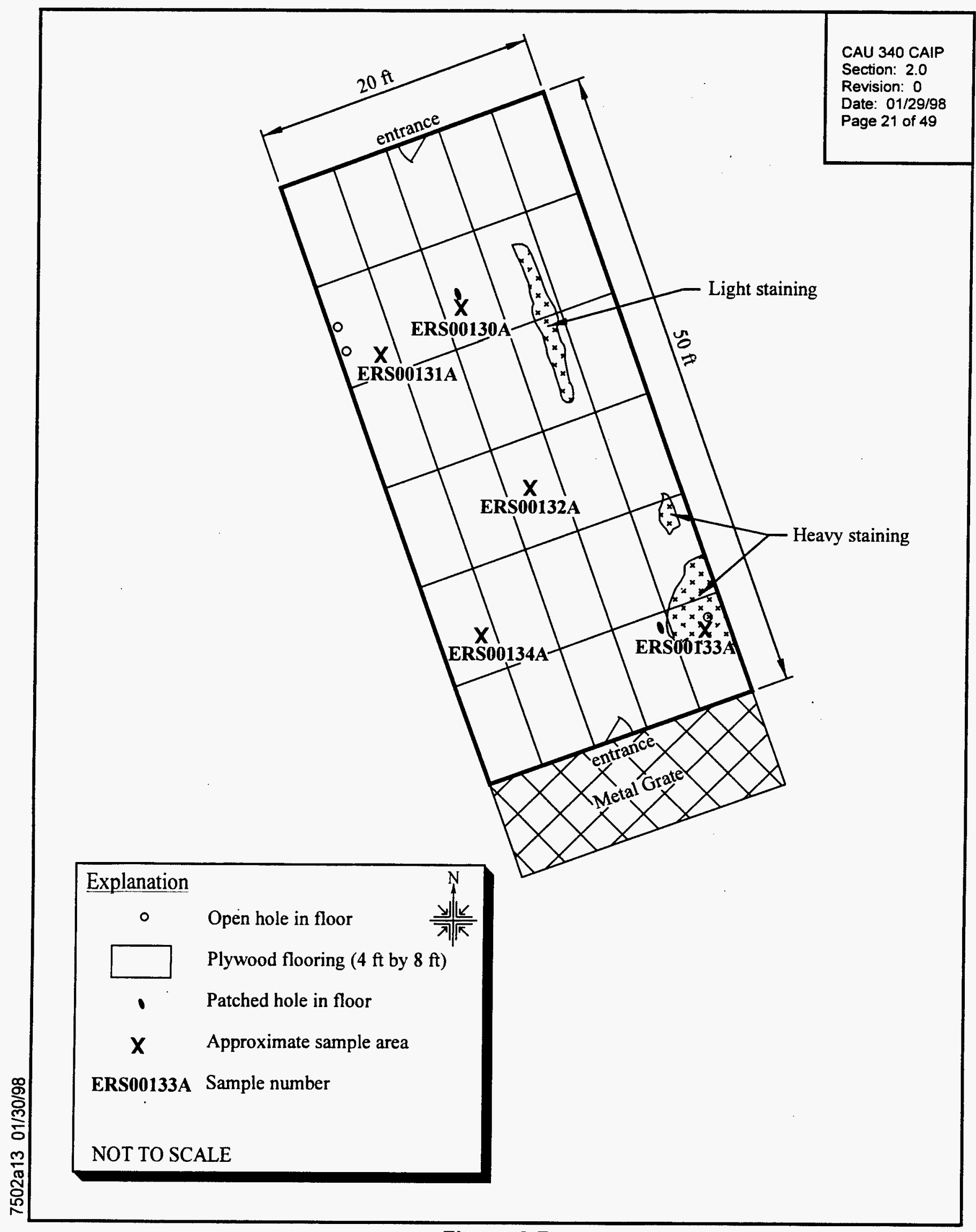

Figure 2-7

Area 15 Quonset Hut 15-11

Preliminary Surface Soil-Sample Locations, September 30, 1997 
Table 2-3

Area 15 Quonset Hut 15-11

Summary Preliminary Sampling Analytical Results for September 30, 1997 Total Pesticides and Herbicides

\begin{tabular}{||l|c|c|c|c|c|}
\hline \multirow{2}{*}{ Pesticide } & \multicolumn{5}{|c|}{ Concentration by Sample (ppm) } \\
\cline { 2 - 6 } & ERS 00130A & ERS 00131A & ERS 00132A & ERS 00133A & ERS 00134A \\
\hline \hline $4,4^{\prime}$-DDD & 0.0046 & 0.0025 & 0.0056 & 0.2 & ND \\
\hline $4,4^{\prime}-$-DE & 0.0035 & ND & ND & 0.15 & ND \\
\hline $4,4^{\prime}$-DDT & 0.038 & 0.017 & 0.036 & 1.7 & 0.0023 \\
\hline Lindane & ND & 0.031 & ND & ND & ND \\
\hline Endrin Aldehyde & ND & ND & 0.0022 & 0.037 & ND \\
\hline Endosulfan I & ND & ND & ND & 0.0088 & ND \\
\hline Endosulfan II & ND & ND & ND & 0.022 & 0.0022 \\
\hline beta-BHCa & ND & ND & ND & ND & 0.0034 \\
\hline
\end{tabular}

${ }^{a}$ Benzene hexachloride

ppm $=$ Parts per million ND $=$ Not detected 


\subsection{Objectives}

The DQOs are qualitative and quantitative statements that specify the quality of the data required to support potential corrective action at the CAU. The DQOs were developed to clearly define the purpose(s) for which environmental data will be used and to aid in the development of a data collection program.

\subsection{Conceptual Site Mode/s}

The conceptual model developed for each of the CASs will serve as the basis for site investigations. The models are formulated on assumptions and premises that were discussed during the DQO process as outlined in Appendix A.

\subsubsection{General Assumptions}

The following are general assumptions that apply to all the conceptual models.

- The COPCs at each CAS are a result of releases from known or potential sources as identified in Section 2.2 and Section 2.4 of this document.

- The future uses of the area will likely be similar to current uses (e.g., support operations).

- Groundwater impacts are not expected because of the large depth to groundwater (Section 2.1.3).

- Environmental conditions at the sites are not conducive to significant downward and lateral migration of COPCs (i.e., arid climate, high evaporation rates, soil type, and generally low permeabilities).

- The extent of COPCs is localized and limited to pesticides, herbicides, and related compounds.

- The most likely exposure pathway is inhalation of airborne dust particles containing COPCs from the disturbance of soil by site workers (e.g., heavy equipment, shovels, drilling).

The field investigation will allow for the reasonable modification or termination of the investigation activities if sufficient data are available to justify a change. If the conceptual model is found through investigation to be unacceptable (e.g., contamination is deeper or more widespread than projected), 
then the model will have failed, and the investigation will be rescoped or contingent plans implemented as specified. Contingency plans for drilling or trenching will be implemented if COPCs extend beyond the reach of hand tools or if soil conditions prevent the use of hand tools. Table 3-1 discusses various aspects that could affect the conceptual models and the associated impacts.

\subsubsection{Site-Specific Conceptual Model for Quonset Hut 800}

The following assumptions and considerations are part of the site-specific conceptual model for Q800:

- Soil near the outfall area (location where pipes discharge to the ditch) will móst likely contain higher concentrations of COPCs than other areas within the investigation area.

- Soil mounds (particularly on the ditch banks) within the CAS could contain COPCs. Soils from the ditch were scraped and placed up on the ditch banks. These soil mounds could contain varying concentrations of COPCs depending on their original location in the ditch.

- Soil below and near the upstream part of the culvert has the potential to have been contaminated by COPCs.

- The discharge pipes (clay, metal) will be managed and disposed of at the conclusion of the investigation.

- The solid/oil separator is considered a part of the Q800 building and will remain with the building until decommissioning.

\subsubsection{Site-Specific Conceptual Model for Skid Huts}

The following assumptions and considerations are part of the site-specific conceptual model for Skid Huts:

- The existing skid hut will be removed from the current location and disposed or salvaged in accordance with the Housekeeping Category CAU Work Plan (DOE/NV, 1996c) prior to soil investigations.

- Areas of potentially significant COPC contamination can generally be identified by stained soils to the north and south of the existing skid hut, near the hose bibb, and to the west of the skid hut near the location where the sink most likely discharged. 
Table 3-1

\section{Explanation of Various Aspects that may Potentially Affect or Impact the} Corrective Action Site Conceptual Models

\begin{tabular}{|c|c|c|}
\hline Aspect & $\begin{array}{l}\text { CAS-Model } \\
\text { Impacted }\end{array}$ & Explanation \\
\hline Topography & None & $\begin{array}{l}\text { No impact from topography at the sites is expected. A sufficient and } \\
\text { reasonable gradient }(\sim 3 \%) \text { exists to allow for equipment access and } \\
\text { investigation of the sites. }\end{array}$ \\
\hline $\begin{array}{l}\text { Geology, } \\
\text { Stratigraphy, } \\
\text { Lithology }\end{array}$ & $\begin{array}{l}\text { Q800 and Skid } \\
\text { Huts }\end{array}$ & $\begin{array}{l}\text { Caliche occurrence in Area } 23 \text { is of variable thickness and extent. If caliche is } \\
\text { encountered, a contingency plan is to drill. } \\
\text { The abundance of gravels, cobbles, and some boulders may potentially limit } \\
\text { use of hand tools for soil sampling; a contingency plan for use of a backhoe or } \\
\text { drill rig will be implemented. }\end{array}$ \\
\hline Climate & All & $\begin{array}{l}\text { Sampling will not be conducted in inclement weather where soil samples may } \\
\text { be compromised (e.g., rain or snow storms). } \\
\text { Regional climate is arid with high evapotranspiration rates, thus limiting } \\
\text { migration of COPCs. }\end{array}$ \\
\hline Hydrogeology & None & $\begin{array}{l}\text { Vertical migration of COPCs is expected to be limited. Soil types are } \\
\text { generally not conducive to downward migration of COPCs, and the depth to } \\
\text { groundwater is large. }\end{array}$ \\
\hline $\begin{array}{l}\text { Floodplain } \\
\text { Studies }\end{array}$ & None & $\begin{array}{l}\text { No impact is expected unless there is significant flooding ( }>100 \text { year storm) at } \\
Q 800 \text { and Skid Huts. }\end{array}$ \\
\hline Equipment & All & $\begin{array}{l}\text { Initial sampling at the CASs will be conducted with hand tools; if sampling } \\
\text { needs to continue beyond the reach or capability of hand tools, or if caliche is } \\
\text { encountered then a contingency plan is to use a backhoe or drill rig to } \\
\text { continue sampling. } \\
\text { At Q15-11, initial investigations will be with hand tools; if deeper sampling } \\
\text { equipment is needed, then rescoping is necessary. }\end{array}$ \\
\hline Infrastructure & All & $\begin{array}{l}\text { Q800: Steam-cleaning operations may need to be stopped if there is a } \\
\text { potential for these operations to interfere with the investigation. } \\
\text { Skid Huts: The hose bibb (water spigot) leak needs to be fixed before } \\
\text { investigation begins. The use of the hose bibb will need to be suspended } \\
\text { (e.g., lockout, tagout, or removal) during investigation. } \\
\text { All: Utility lines or structures will be identified before investigations begin. }\end{array}$ \\
\hline Geotechnical & None & $\begin{array}{l}\text { At this time, COPCs are expected to be of relatively limited vertical and lateral } \\
\text { extent. Because COPCs are expected to be near the surface, geotechnical } \\
\text { data will not be obtained. }\end{array}$ \\
\hline
\end{tabular}


- Soil containing COPCs on the north and west side of the existing skid hut could have been redistributed from the immediate area during the grading of the roadway and flood control channel.

- If COPCs extend beyond the investigation area, then the sampling plan will need to be reevaluated.

- The vertical extent of COPCs is expected to be shallow (within the reach of hand tools) near the expected sink drainage location. The supply line is about $1 / 2$ centimeter $(\mathrm{cm})(3 / 8$ inch [in.]) diameter and not suitable for conveying large volumes of water.

- The area near the hose bibb was used for mixing and rinsing containers (IT, 1997a). In this area the vertical extent of COPC contamination is expected to be the deepest for the site, but still within the reach of a hand tools.

\subsubsection{Site-Specific Conceptual Model for Quonset Hut 15-11}

The following assumptions and considerations are part of the site-specific conceptual model for the Area 15 Q15-11:

- The plywood floor will be managed as follows: stacked and protected from the elements, and a waste management sample will be taken to ensure correct disposal.

- Stained soil beneath the plywood flooring in Q15-11 will contain higher concentrations of COPCs.

- COPC contamination is of minor vertical and lateral extent, and the use of hand tools will be appropriate for investigation. The extent of COPCs is limited to the investigation area of Q15-11.

- No water source, sink, or drainage appears to have ever been installed at Q15-11.

- The Q15-11 building will remain in place until sampling results have been evaluated or a corrective action decision has been made.

The assumptions were used to develop a sampling strategy (Section 4.1) to ensure that sampling activities provide data that are meaningful and valid and will lead to a technically defensible corrective action plan. 


\subsection{Contaminants of Potential Concern}

The COPCs are pesticides, herbicides, and related compounds as identified through review of site history documentation, process knowledge, preliminary sampling results, and personnel interviews associated with each of the CASs. Samples collected will be analyzed initially for a broad suite of

COPCs. Subsequent sampling stages, if necessary, may use a reduced or expanded list of COPC parameters if justified by analytical results. The parameters to be analyzed are:

- Total pesticides

- Total herbicides

- Total petroleum hydrocarbons (gasoline and diesel)

- RCRA Metals

- Toxicity Characteristic Leaching Procedure (TCLP) (metals and pesticides)

- SVOCs

- VOCs

- Alpha, beta, and gamma emitters

\subsection{Preliminary Action Levels}

The preliminary action levels (PALs), as agreed to during the DQO process, for on-site field screening will be used to determine the presence of COPCs above levels of concern. The field screening PALs that indicate action is required are as follows:

- Volatile organic compound headspace screening levels at $20 \mathrm{ppm}$ in a closed system or 2.5 times background, whichever is higher

- $100 \mathrm{ppm}$ TPH concentration using a colorimetric field screening technique (e.g., Hanby Brand or similar)

- 600 parts per billion (ppb) ( 0.60 milligrams per kilogram [mg/kg]) chlordane concentration using an immunoassay field-screening technique (e.g., Millipore Brand or similar). The immunoassay kits are being evaluated for their usefulness in the field and kit results will be correlated to laboratory results.

- $1.0 \mathrm{ppm}(1.0 \mathrm{mg} / \mathrm{kg})$ DDT and metabolites DDD and DDE concentration using an immunoassay field-screening technique (e.g., Millipore Brand or similar). The immunoassay kits are being evaluated for their usefulness in the field. These results will be correlated to laboratory results. 
- Levels twice the established daily background for soil samples. Radiological surveys (alpha/beta) are conducted daily to establish site-specific background levels at the site.

- Levels twice those listed for surface contamination in the DOE Nevada Test Site/Yucca Mountain Project Radiological Control Manual (DOE/NV, 1996f).

The PALs for off-site laboratory analytical results will be used to determine if Stage II and/or additional sampling is necessary for the Q800 and Skid Huts CASs. These PALs are as follows:

- NDEP Corrective Action Regulation (NAC 445A [NAC,1996a]) levels for initial site investigation. Risk-based levels based on modeling may be used as an alternative.

- $100 \mathrm{ppm}$ TPH action level (gasoline and diesel) (NAC 445A [NAC,1996a])

- Levels twice the established daily background for soil samples. Radiological surveys (alpha/beta) are conducted daily to establish site-specific background levels at the site.

- Levels twice those listed for surface contamination in the DOE Nevada Test Site/Yucca Mountain Project Radiological Control Manual (DOE/NV, 1996f).

\subsection{Data Quality Objectives Process}

Identification of parameters and laboratory analyses for soil samples were determined as part of the DQO process (Appendix A). These analyses will provide the means for the quantitative measurement of COPC concentrations. The analytical methods and minimum reporting limits for each parameter are provided in Table 3-2. The TCLP analyses and regulatory limits are shown in Table 3-3 for metals and pesticides. The precision and accuracy requirements are those stated in the latest revision of the individual EPA SW-846 methods (EPA, 1996). 
Table 3-2

Laboratory Analytical Requirements for the CAU 340 Pesticide Release Sites (Page 1 of 2)

\begin{tabular}{|c|c|c|c|}
\hline Parameter & Medium $^{a}$ & Analytical Method & $\begin{array}{l}\text { Minimum Laboratory } \\
\text { Reporting Limit }\end{array}$ \\
\hline \multirow{2}{*}{ Total VOCs } & Water & \multirow{2}{*}{$8260^{c}$} & \multirow{2}{*}{$\begin{array}{l}\text { Analyte-specific estimated } \\
\text { quantitation limits }^{d}\end{array}$} \\
\hline & Soil & & \\
\hline \multirow{2}{*}{ Total SVOCs } & Water & \multirow{2}{*}{$8270^{\circ}$} & \multirow{2}{*}{$\begin{array}{l}\text { Analyte-specific estimated } \\
\text { quantitation limits }^{\mathrm{d}}\end{array}$} \\
\hline & Soil & & \\
\hline \multicolumn{4}{|l|}{ Total RCRA Metals } \\
\hline Arsenic & \multirow{8}{*}{ Water } & \multirow{8}{*}{$6010 / 7470^{c}$} & $10 \mu g / L$ \\
\hline Barium & & & $200 \mu \mathrm{g} / \mathrm{L}$ \\
\hline Cadmium & & & $5 \mu g / L$ \\
\hline Chromium & & & $10 \mu \mathrm{g} / \mathrm{L}$ \\
\hline Lead & & & $3 \mu \mathrm{g} / \mathrm{L}$ \\
\hline Mercury & & & $0.2 \mu \mathrm{g} / \mathrm{L}$ \\
\hline Selenium & & & $5 \mu \mathrm{g} / \mathrm{L}$ \\
\hline Silver & & & $10 \mu g / L$ \\
\hline \multicolumn{4}{|l|}{ Total RCRA Metals } \\
\hline Arsenic & & \multirow{8}{*}{$6010 / 7470^{c}$} & $1 \mathrm{mg} / \mathrm{kg}$ \\
\hline Barium & & & $20 \mathrm{mg} / \mathrm{kg}$ \\
\hline Cadmium & & & $0.5 \mathrm{mg} / \mathrm{kg}$ \\
\hline Chromium & Soil & & $1 \mathrm{mg} / \mathrm{kg}$ \\
\hline Lead & & & $0.3 \mathrm{mg} / \mathrm{kg}$ \\
\hline Mercury & & & $0.1 \mathrm{mg} / \mathrm{kg}$ \\
\hline Selenium & & & $0.5 \mathrm{mg} / \mathrm{kg}$ \\
\hline Silver & & & $1 \mathrm{mg} / \mathrm{kg}$ \\
\hline \multirow{2}{*}{ Total Pesticides } & Water & \multirow{2}{*}{$8080^{\circ}$} & \multirow{2}{*}{$\begin{array}{l}\text { Analyte-specific estimated } \\
\text { quantitation limits }^{d}\end{array}$} \\
\hline & Soil & & \\
\hline \multirow{2}{*}{ Total Herbicides } & Water & \multirow{2}{*}{$8150^{c}$} & \multirow{2}{*}{$\begin{array}{l}\text { Analyte-specific estimated } \\
\text { quantitation limits }^{\mathbf{d}}\end{array}$} \\
\hline & Soil & & \\
\hline \multirow{4}{*}{ TPH } & Water (gasoline) & \multirow{4}{*}{8015 modifiedc $^{c}$} & $1 \mathrm{mg} / \mathrm{L}$ \\
\hline & Water (diesel) & & $1 \mathrm{mg} / \mathrm{L}$ \\
\hline & Soil (gasoline) & & $1 \mathrm{mg} / \mathrm{kg}$ \\
\hline & Soil(diesel) & & $30 \mathrm{mg} / \mathrm{kg}$ \\
\hline
\end{tabular}


Table 3-2

\section{Laboratory Analytical Requirements for the CAU 340 Pesticide Release Sites} (Page 2 of 2)

\begin{tabular}{|c|c|c|c|}
\hline Parameter & Medium ${ }^{a}$ & Analytical Method & $\begin{array}{l}\text { Minimum Laboratory } \\
\text { Reporting Limit }\end{array}$ \\
\hline \multirow{2}{*}{$\begin{array}{l}\text { Gross Alpha Emitting } \\
\text { Radionuclides }\end{array}$} & Water & EPA $900.0^{c}$ & $1 \mathrm{pCi} / \mathrm{L}^{\mathrm{h}}$ \\
\hline & Soil & SM $7110^{\prime}$ & $10 \mathrm{pCi} / \mathrm{g}^{\mathrm{h}}$ \\
\hline \multirow{2}{*}{$\begin{array}{l}\text { Gross Beta Emitting } \\
\text { Radionuclides }\end{array}$} & Water & EPA $900.0^{e}$ & $4 \mathrm{pCi} / \mathrm{L}^{\mathrm{n}}$ \\
\hline & Soil & $\operatorname{SM} 7110^{f}$ & $10 \mathrm{DCi} / \mathrm{g}^{\mathrm{h}}$ \\
\hline \multirow{2}{*}{ Gamma Emitting Radionuclides } & Water & EPA $901.1^{\mathrm{e}}$ & $20 \mathrm{pCi} / L^{\mathrm{nj}}$ \\
\hline & Soil & HASL $300,4.5 .2 .3^{9}$ & $0.2 \mathrm{pCi} / \mathrm{g}^{\mathrm{hj}}$ \\
\hline
\end{tabular}

"QC (water) samples are included in table

'Industrial Sites Quality Assurance Project Plan (DOE/NV, 1996d)

'EPA Test Methods for Evaluating Solid Waste, 3rd Edition, Parts 1-4, SW-846 (EPA, 1996)

dEstimate: Quantitation Limit (EQL) as given in SW 846 Method, U.S. EPA (EPA, 1996)

- Prescribed Procedures for Measurement of Radioactivity in Drinking Water(EPA, 1980)

'Standard Methods for the Examination of Water and Wastewater, American Public Health Association, 1992

-Environmental Measurements Laboratory Procedure Manual, HASL-300, U.S. Department of Energy (DOE, 1992)

"Values given are typical laboratory minimum reporting limits, and actual values could vary depending on laboratory, soil type, and specific radionuclide

For Cesium-137

$$
\begin{aligned}
& \text { EPA }=\text { U.S. Environmental Protection Agency } \\
& \mathrm{mg} / \mathrm{kg}=\text { Milligram(s) per kilogram } \\
& \mathrm{mg} / \mathrm{L}=\text { Milligram(s) per liter } \\
& \text { RCRA }=\text { Resource Conservation and Recovery Act } \\
& \mathrm{SVOC}=\text { Semivolatile organic compound(s) } \\
& \mathrm{VOC}=\text { Volatile organic compound(s) } \\
& \mu \mathrm{g} / \mathrm{L}=\text { Microgram(s) per liter } \\
& \mathrm{pCi/g}=\text { Picocurie(s) per gram } \\
& \mathrm{pCi} / \mathrm{L}=\text { Picocurie(s) per liter }
\end{aligned}
$$


Table 3-3

Toxicity Characteristic Leaching Procedure Analytical Requirements for the CAU 340 Pesticide Release Sites

\begin{tabular}{|c|c|c|c|c|}
\hline TCLP Parameter and Analyte & Mediumb & $\begin{array}{l}\text { Analytical } \\
\text { Method }\end{array}$ & $\begin{array}{c}\text { Minimum } \\
\text { Detectable } \\
\text { Concentration } \\
\text { (mg/L) }\end{array}$ & $\begin{array}{c}\text { Regulatory } \\
\text { Limitc } \\
(\mathrm{mg} / \mathrm{L})\end{array}$ \\
\hline TCLPa Metals & \multirow{9}{*}{ Water or Soil } & \multirow{9}{*}{$\begin{array}{c}1311 / 6010 \\
1311 / 7000 \\
\text { series }^{d}\end{array}$} & & \\
\hline Arsenic & & & 0.300 & 5.0 \\
\hline Barium & & & 0.200 & 100.0 \\
\hline Cadmium & & & 0.005 & 1.0 \\
\hline Chromium & & & 0.010 & 5.0 \\
\hline Lead & & & 0.100 & 5.0 \\
\hline Mercury & & & 0.0002 & 0.20 \\
\hline Selenium & & & 0.250 & 1.0 \\
\hline Silver & & & 0.010 & 5.0 \\
\hline TCLPa Pesticides & \multirow{8}{*}{ Water or Soil } & \multirow{8}{*}{$1311 / 8080 A^{d}$} & & \\
\hline Chlordane & & & 0.005 & 0.03 \\
\hline Endrin & & & 0.0005 & 0.02 \\
\hline Heptachlor & & & 0.0005 & 0.008 \\
\hline Heptachlor epoxide & & & 0.0005 & 0.008 \\
\hline Lindane & & & 0.0005 & 0.4 \\
\hline Methoxychlor & & & 0.001 & 10.0 \\
\hline Toxaphene & & & 0.020 & 0.5 \\
\hline
\end{tabular}

'Toxicity Characteristic Leaching Procedure (CFR, 1996)

${ }^{b} \mathrm{QC}$ (water) samples are included in table

'40 Code of Federal Regulations 261.24, updated (CFR, 1996)

'EPA Test Methods for Evaluating Solid Waste, 3rd Edition, Parts 1-4, SW-846 (EPA, 1996)

$\mathrm{mg} / \mathrm{L}=$ Milligram(s) per liter 


\subsection{Field Investigation}

This section of the CAIP contains the sampling strategy and sample collection methods for investigating CAU 340 . The sampling results will be used to substantiate or refute the conceptual models, to determine waste types for appropriate waste minimization options and management requirements, and to support the corrective action decision process. Data are being collected during the field investigations to establish the type, concentration, and extent of COPCs.

\subsection{Two - Staged Sampling Strategy}

The sampling strategy for these sites is designed to provide a sufficient amount of quality data for a technically defensible and cost-effective corrective action for this site. The sampling strategy will ensure samples are representative of ambient conditions and of acceptable quality. Because preliminary sampling data indicate the presence of COPCs, a biased and judgmental approach will be used to define the probable extent of contamination. A random method of sampling is not adequate for defining the extent of COPCs.

To facilitate the evaluation of each conceptual model, the sampling investigation will be divided into two stages. The purpose of the first stage of sampling is to identify and evaluate the distribution of COPCs throughout the investigation area on a wide scale. Also during Stage I, sampling of expected worst-case areas will allow for the evaluation of the vertical extent of COPCs. The Stage I surface and shallow-subsurface ( 0 to $2.0 \mathrm{~m}$ [ 0 to $6 \mathrm{ft}$ ) soil samples collected will be analyzed for a broad range of parameters.

The second stage of sampling, if necessary, will continue to evaluate the extent of COPCs throughout the investigation area on a narrower scale. This stage of the investigation will be used to refine and/or supplement data needs (e.g., reduce or expand the parameter list). The location of Stage II samples will be determined based on process knowledge, preliminary data, results from Stage I sampling, and visual evaluation of the CASs. The CASs, as a group, may be investigated concurrently in a single phase or consecutively in separate phases. The following are descriptions, rationale, and contingencies for activities to be conducted for field investigations during Stage I and/or Stage II 
sampling at each CAS. Contingent investigations may be carried out as part of the current or subsequent sampling stages.

\subsubsection{Stage / Sampling}

In general, the Stage I sampling activities for the CAS investigation areas are as follows:

- Collect surface and shallow subsurface soil samples with hand tools on a widely-spaced grid scale pattern (e.g., sampling points will be roughly of equal distance and spacing) throughout the investigation areas. Planned sample locations for Q800 are shown in Figure 4-1; sample locations for Skid Huts are shown in Figure 4-2; and those for Q15-11 are shown in Figure 4-3. The actual location and number of samples collected could vary.

- Collect surface and shallow subsurface soil samples with hand tools from expected worst-case areas as described in the conceptual models (Section 3.1). The following worst-case areas include:

- Q800 site (Figure 4-1): the area near the outfall where water tended to pond (upstream section of the culvert), the entire length of the ditch bottom, and soil mounds on the ditch banks

- Skid Huts (Figure 4-2) site: the area near the hose bibb where pesticides and herbicides were mixed and the excess rinsate from applicators was dumped on the ground, the area where the sink drained to ground, and stained areas north and south of the existing skid hut

- Q15-11 site (Figure 4-3): stained soil areas

- Stage I samples will be analyzed for a broad suite of parameters (Table 3-2) for identification and quantification of COPCs. A quick turnaround on analytical results for selected samples may be requested.

- Conduct field screening of excavated soils for evaluation of VOCs, TPH, chlordane, and DDT.

- Conduct radiological field surveys.

- If the use of hand tools are ineffective (e.g., because of adverse soil conditions including caliche, cobbles, boulders) for soil sampling, or if soil sampling is necessary beyond the reach of hand tools, then a contingent plan is to utilize a backhoe and/or drill rig to continue the investigation during Stage II. 


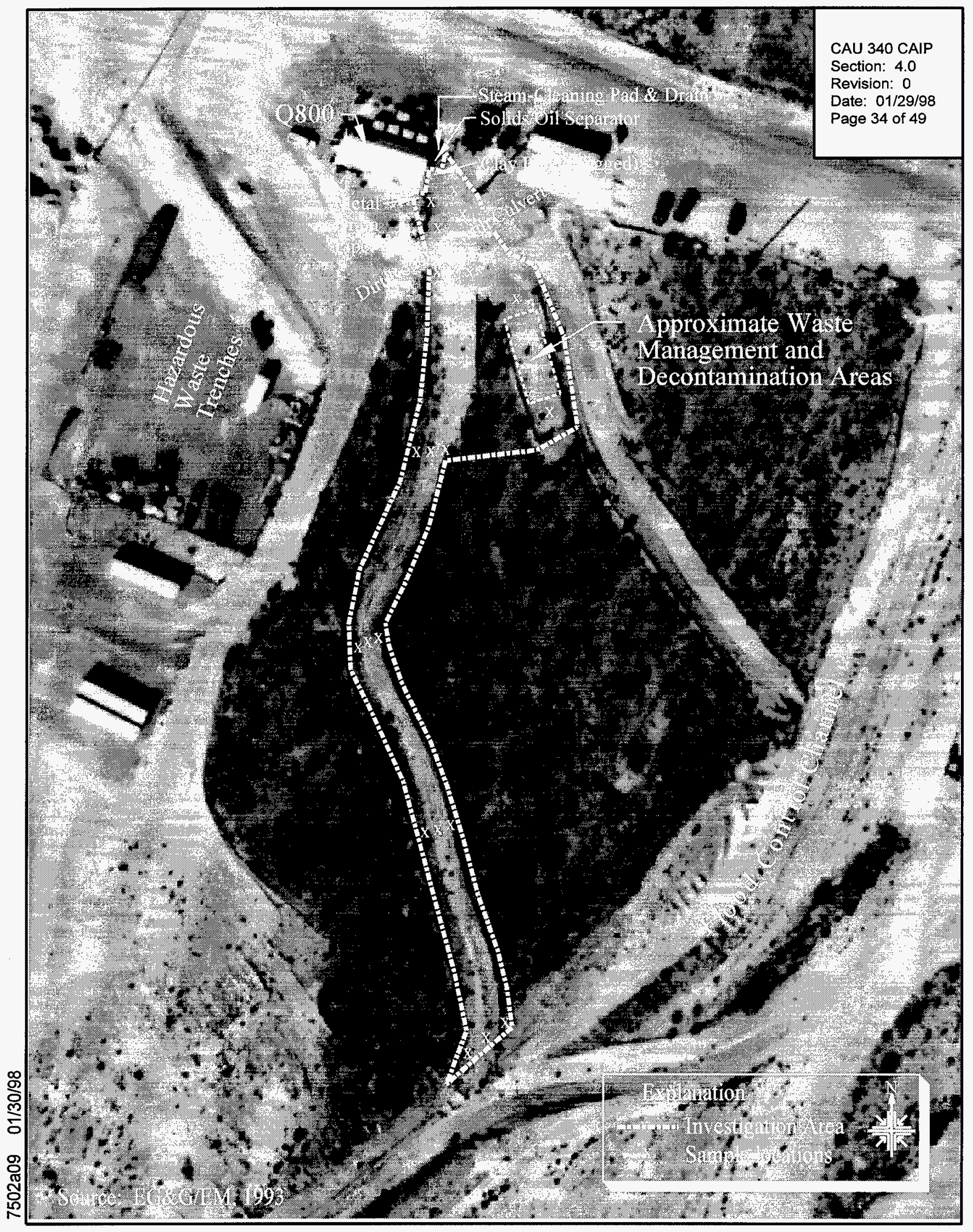

Figure 4-1

Area 23 Quonset Hut 800 Planned Soil Sample Locations 


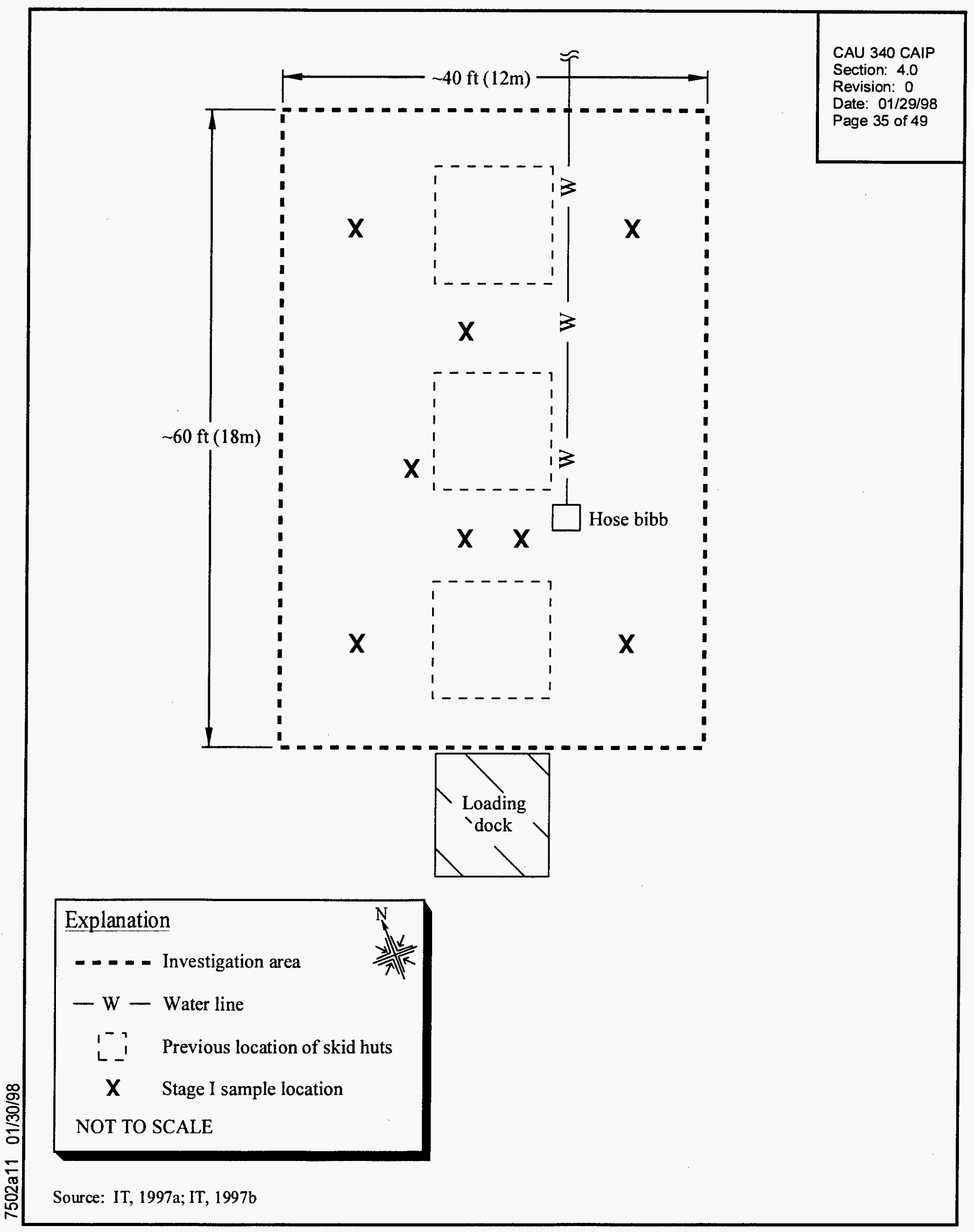

Figure 4-2

Area 23 Skid Huts Planned Soil Sample Locations 


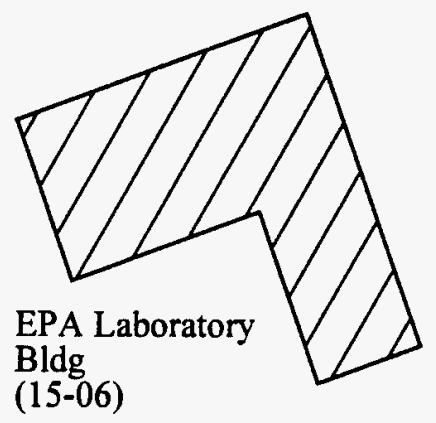

Quonset shop (15-10)

Quonset Hut 15-11 Investigation Area

Metal grate for parking

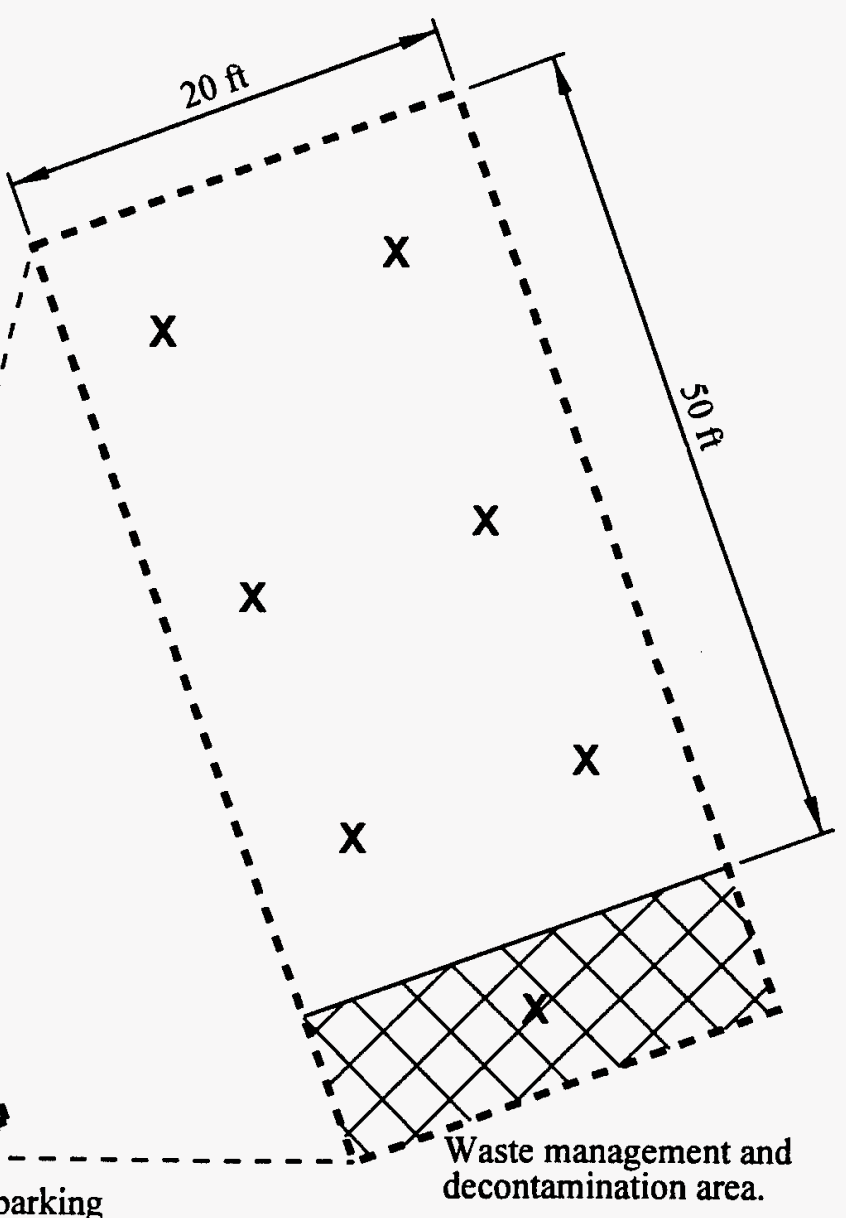

Explanation

- - - Investigation area

Waste management and decontamination area

$X \quad$ Soil-sample location

Buildings removed during decontamination and decommissioning, 1997.

Note: Metal grate was removed during decontamination and decommissioning activities, 1997.

NOT TO SCALE 


\subsubsection{Stage II Sampling}

The Stage II sampling activities for the CAS investigation areas are as follows:

- At Q800 and Skid Huts, the Stage II investigation is optional. If necessary, additional surface or shallow-surface soil samples will be collected. Additional sample locations will be based on process knowledge, preliminary data, quick turnaround results from Stage I, field-screening results, or visual evaluation.

- No Stage II sampling is planned for the Q15-11 site.

- If necessary, implement contingent sampling methods (i.e., trenching and/or drilling) for deeper subsurface investigation. A contingency plan will be implemented if hand tools prove ineffective for collection of soil samples or if the depth of COPCs (established in Stage I) extend beyond the reach of hand tools.

\subsection{Sample Collection and Decontamination Procedures}

All collected soil samples, including quality assurance and quality control (QA/QC) samples will be collected in accordance with Standard Operating Procedures Manual (DOE/NV, 1994c) and the Industrial Sites QAPP (DOE/NV, 1996d). Records will be kept of the soil description, field-screening measurements, and all other relevant data. All pertinent and required sampling information (i.e., date, time, sample interval) will be documented. All samples will be accompanied by the appropriate Chain of Custody documentation to ensure the defensibility of the data.

All equipment which contacts the soil will be decontaminated between samples in accordance with the DOE/NV Environmental Restoration Division (ERD) Procedure ERD-05-701, "Sampling Equipment Decontamination," Rev. 0 (DOE/NV, 1994b) to minimize the potential for cross-contamination between samples.

\subsection{Surface and Shallow Subsurface Soil Samples}

The alluvial material makes soil sampling conditions less than ideal because of the abundance of gravel. cobbles, and some boulders. Core samplers and hand augers (manual or powered) cause less disturbance of soil samples, which is useful when analyzing for VOCs and SVOCs. If these tools are not effective because of the poorly sorted alluvial material, then hand tools such as a scoop, shovel, post-hole digger, or other acceptable tool may be utilized. 
Surface soil samples 0 to $0.2 \mathrm{~m}$ ( 0 to 6 in.) and shallow-subsurface soil samples 0.2 to $2.0 \mathrm{~m}$ ( 6 in. to $6 \mathrm{ft}$ ) will be collected from the investigation area using hand tools. The approximate vertical sampling intervals for shallow subsurface soil samples will start at the ground surface 0 to $0.2 \mathrm{~m}(0$ to 6 in.) and continue at $0.33 \mathrm{~m}(1 \mathrm{ft})$ intervals for $2 \mathrm{~m}(\sim 6 \mathrm{ft})$. Sampling will continue until field screening indicates that two consecutive results below the field PALs (confirmed through laboratory analyses) have been obtained. If COPCs extend beyond the reach of hand sampling capabilities [2.0 $\mathrm{m}(6 \mathrm{ft})]$ or if hand sampling is ineffective, then contingent sampling methods (e.g., trenching, drilling) will be used.

\subsection{Contingency Subsurface Soil Sampling Methods}

Subsurface soil sampling, for the purposes of this report, is considered to be anything deeper than the reach of hand tools $(\sim 2.0 \mathrm{~m}$ or $[6 \mathrm{ft}])$. The following provides a brief description of contingent soil sample collection methods that may be used if sampling is necessary beyond $2.0 \mathrm{~m}(\sim 6 \mathrm{ft})$, or if sampling with hand tools is ineffective. Contingent methods, if necessary, will be implemented in Stage II of the investigation for this CAU.

\subsubsection{Trenching}

If trenching is used as a contingent soil sampling method for the Q800 and Skid Huts sites, then excavation will be conducted with a backhoe equipped with a narrow bucket (about $0.33 \mathrm{~m}[1.0 \mathrm{ft}]$ ). At Q800, the trenches will transect the ditch at three locations. The locations of the trenches will be in the upper reach near the outfall, at midsection, and in the lower reach before the intersection with the flood control channel. Each trench will be about $0.33 \mathrm{~m}(1.0 \mathrm{ft})$ wide and extend across the ditch in varying lengths to about $1.5 \mathrm{~m}(5 \mathrm{ft})$ beyond the bank edges. The depth of these trenches will vary depending on the extent of COPCs. At the Skid Huts, a small trench (test pit) will be excavated near the hose bibb with initial dimensions about $0.50 \mathrm{~m}$ to $1.0 \mathrm{~m}(1.5 \mathrm{ft}$ to $3 \mathrm{ft})$ in diameter.

Soil samples will be collected with a stainless steel scoop from the center of the backhoe bucket immediately upon retrieval. Soil samples will start being collected $0.33 \mathrm{~m}(1.0 \mathrm{ft})$ below the last previously collected sample. The vertical profile for sample collection starting at ground surface is $0.3-\mathrm{m}(1.0-\mathrm{ft})$ intervals for $1.0 \mathrm{~m}(3 \mathrm{ft})$ and $0.6-\mathrm{m}(2-\mathrm{ft})$ intervals from $1.0 \mathrm{~m}$ to $4 \mathrm{~m}(3$ to $12 \mathrm{ft})$. Sampling will continue until field screening indicates that two consecutive results below field PALs 
(confirmed through laboratory analyses) have been obtained. If sampling needs to continue deeper than $4 \mathrm{~m}(12 \mathrm{ft})$ or the maximum reach of a backhoe, then a contingency plan for drilling will be implemented.

\subsubsection{Drilling}

If drilling is used as a contingent sampling method for sample collection at the Q800 and Skid Huts sites, a hollow-stem auger with a split spoon sampler or core barrel will most likely be used.

Soil samples will be collected using a split-spoon sampler or core barrel at $1.5-\mathrm{m}(5-\mathrm{ft})$ intervals beginning $1.5 \mathrm{~m}(5 \mathrm{ft})$ below the last previously collected sample and continuing, if needed, to a maximum depth of $15 \mathrm{~m}(50 \mathrm{ft})$. If drilling is required below $15 \mathrm{~m}(50 \mathrm{ft})$, the sampling interval will be increased to $3 \mathrm{~m}$ (10 ft). Before terminating drilling, two consecutive results below PALs (as identified through on-site field-screening methods) will be obtained at $1.5 \mathrm{~m}$ and $3 \mathrm{~m}$ ( $5 \mathrm{ft}$ and $10 \mathrm{ft}$ ) below the last zone where COPCs were present. These results will be confirmed through laboratory analyses. If drilling is required beyond $22.5 \mathrm{~m}(\sim 75 \mathrm{ft})$, then rescoping is necessary.

\subsection{Field Screening}

Field screening will be performed on soil samples collected during site investigations to provide semiquantitative measurements of specified COPCs within the soil. Field-screening methods will include headspace testing for VOCs, TPH, chlordane, and DDT. The field-screening immunoassay test kits for chlordane and DDT are being evaluated for their effectiveness in the field at the NTS. The results from field screening will be correlated with laboratory results. Field-screening data provide information that assist in guiding investigation needs. If field-screening results exceed the PALs (Section 3.3), then sampling will continue deeper until two consecutive screening results below PALs have been obtained. These data will be used to assist in the selection of samples to be submitted for laboratory analyses. Radiological surveys for alpha and beta emitting radionuclides will also be conducted. 


\subsection{Waste Management}

Based on process knowledge, radioactive and listed hazardous wastes are not anticipated at any of the CASs. Therefore, if contaminants are identified, they will be treated as characteristic rather than listed hazardous wastes. As discussed in Section 2.5.1, preliminary sample results indicate the presence of RCRA TC compounds above regulatory limits in the soil at the Q800 site. Management of Investigation-Derived Waste (IDW) generated at this location will be based, in part, on these preliminary sample results. Similarly, the results of the preliminary samples collected at the Skid Huts site and Q15-11 will be used to aid in making further IDW management decisions.

Waste generated through sampling activities will be traceable to its source and to individual samples. Administrative controls (e.g., decontamination procedures, soil sampling methods, and investigation strategies) will minimize waste generated during site investigation activities. Decontamination activities will be performed in accordance with approved procedures as specified in the field instructions (written prior to commencement of field work) and will be designated according to the COPCs present at the site.

If laboratory results indicate waste is radioactive or mixed, the waste will be managed in accordance with the Nevada Test Site Waste Acceptance Criteria (NTSWAC) (DOE/NV, 1996e) and the "Mutual Consent Agreement Between the State of Nevada and the U.S. Department of Energy for the Storage of Low-Level Land Disposal Restricted Mixed Waste" (NDEP, 1995), respectively. In addition, all drilling and/or trenching will be terminated, and NDEP will be notified. The final waste determination for all IDW will be based on the CFR Title 40 Part 261, "Identification and Listing for Hazardous Waste" and as outlined in Table 5-1 (CFR, 1996).

\subsection{Waste Minimization}

Investigation activities have been designed to minimize the amount of waste generated. Excavated soil that does not require management as radioactive or other regulated waste may be used as fill material when appropriate. Other waste, such as disposable sampling and personal protective equipment, will be considered "Hazardous Waste Awaiting Analysis" and will be segregated to the greatest extent possible to avoid commingling with other solid waste. Hazardous materials will be 
Table 5-1

Action Levels for Investigation-Derived Waste Contaminants

\begin{tabular}{|l|l|l|l||}
\hline \multicolumn{1}{|c|}{ Parameter } & \multicolumn{1}{|c|}{ Action Level } & \multicolumn{1}{c|}{ Source } & \multicolumn{1}{c|}{ Comments } \\
\hline \hline TPH $^{\mathrm{a}}$ & $100 \mathrm{mg} / \mathrm{kg}^{\mathrm{b}}$ & NAC $^{\mathrm{c}} 459.9973$ & Regulated by the NDEP $^{\mathrm{d}}$ \\
\hline $\begin{array}{l}\text { TCLP or Total VOCs } \\
\text { SVOCs', pesticides, } \\
\text { herbicides and RCRA } \\
\text { metals }\end{array}$ & Table 1 of 40 CFR 261.24 & $40 \mathrm{CFR}^{\mathrm{h}} 261$ & \\
\hline Radiological & Isotope-specific & NTS POC & \\
\hline
\end{tabular}

"Total petroleum hydrocarbon(s)

'Milligram(s) per kilogram

'Nevada Administrative Code (NAC), 1996b

'Nevada Division of Environmental Protection

Volatile organic compound(s)

${ }^{\dagger}$ Semivolatile organic compound(s)

Resource Consenvation and Recovery Act ,

${ }^{\text {h}}$ Code of Federal Regulations (CFR, 1996)

' Nevada Test Site Performance Objective Criteria (POC) for Certification of Nonradioactive Hazardous Waste(BN, 1995)

controlled, minimizing generation of hazardous waste, and waste segregation will be applied to all identified waste streams in accordance with approved contractor procedures.

\subsection{Potential Waste Streams}

There is no evidence to indicate chemicals other than pesticides and herbicides were disposed of at any of the three CASs. Therefore IDW will be considered characteristic, rather than listed. There is no evidence to indicate that radioactive or mixed wastes will be generated. However, there is some potential that industrial waste water containing small amounts of oils, greases, and custodial cleaning solutions may have been disposed of through the sinks in Q800 and at the Skid Huts site.

Field-screening methods used during the investigation could contain reagents that produce small quantities of hazardous wastes. These waste streams will be segregated and managed as follows:

- Waste will be accumulated at or near the point of generation.

- The waste will be compatible with the container.

- All containers will meet Department of Transportation (DOT) specifications 
- The container will be in good condition and free from corrosion and dents that impair the integrity of the container.

- At a minimum, the container will be labeled with the following information:

- The words "Hazardous Waste"

- All applicable EPA waste numbers

- Contact name

Wastes generated during the investigation activities may include, but are not limited to, the following:

- Decontamination rinsate

- Contaminated disposable sampling equipment (e.g., plastic, paper, aluminum foil, and sample containers)

- Personal protective equipment

- Contaminated soil

- Plastic sheeting

- Sanitary (e.g., nonhazardous trash) waste

- Field-screening kit waste

\subsection{Investigation-Derived Waste Management}

All waste will be managed on site within the defined investigation area until analytical results are received and the disposition of the waste is determined. By following approved contractor procedures, sampling personnel will ensure that no additional contaminants are added to the waste. At a minimum, IDW will be containerized and recorded. The containers will be appropriately marked and labeled in accordance with DOT and RCRA requirements in and 49 CFR 172 (CFR, 1997b) and 40 CFR 262 (CFR, 1997a). Access to waste temporarily accumulated at the project site will be controlled by placing the waste within an access-controlled area. Based on process knowledge and analytical results from preliminary samples, IDW will be managed as "Hazardous Waste, Pending Analysis" in a temporary 90-Day Hazardous Waste Accumulation Area (HWAA) at the site of generation. 
Waste will be segregated into a minimum of four waste streams: potentially contaminated solid waste, potentially contaminated liquid waste (i.e., decontamination rinsate), hazardous waste generated from field-screening kits, and potentially contaminated soil. Each waste stream will be segregated, and additional segregation may occur within each waste stream.

- Solid materials other than soil wastes are hazardous or hydrocarbon-contaminated waste only by virtue of contact with contaminated media. The same is true o decontamination rinsate. The final waste determination for these wastes will be based on the laboratory results for the associated soil samples and process knowledge. Therefore, sampling and analysis of these waste streams, separate from site investigation analyses, will not be required.

- Hazardous waste generated through the use of field-screening kits will be managed on site in the HWAA.

- IDW soil generated from sampling activities will be containerized and managed within the investigation area until a final waste determination can be made.

\subsubsection{Sanitary Waste}

Sanitary waste (e.g., nonhazardous trash) will be contained in plastic bags, dumpsters, or drums and transported to an NTS-managed solid waste management unit.

\subsubsection{Hydrocarbon Waste}

Hydrocarbon waste (containing more than $100 \mathrm{mg} / \mathrm{kg}$ TPH) will be properly containerized in bags, drums, or roll-off boxes and will be transported to the Area 6 Hydrocarbon Landfill (NAC, 1996b).

\subsubsection{Hazardous Waste}

Hazardous waste generated by the use of field-screening kits will be managed in a HWAA. The IDW marked as "Hazardous Waste Pending Analysis" will be managed in the HWAA until its regulatory status can be determined through interpretation and evaluation of laboratory results.

Prior to or on the 120th day of accumulation pursuant to a 30-day extension (40 CFR 262.34 (4) (b)) being granted by the NDEP, hazardous waste will be shipped by a licensed/permitted hazardous waste transporter to a permitted treatment storage and disposal facility (CFR, 1997a). If this request is not granted, hazardous waste will be shipped prior to or on the 90th day of accumulation, if possible. When appropriate, a copy of the uniform hazardous waste manifest shall be provided to the NDEP. 


\subsection{Duration and Records Availability}

\subsection{Duration}

The following tentative schedule of activities (in calendar days) will be initiated after the submittal of the Final CAIP to the DOE/NV.

- Day 0: Preparation for field work will begin.

- Day 30: NDEP approval of the CAIP

- Day 35: The field work, including field screening and sampling, will begin.

- Day 85: The field work will be completed, and samples will have been shipped to the laboratory for analysis.

- Day 170: The quality-assured laboratory analytical sample data will be available for review.

- The FFACO deadline for the Corrective Action Decision Document (CADD) is 11/30/98 (Liebendorfer, 1997).

The following information will be reported in the CADD:

- Introduction, including purpose, scope, a FFACO cross-walk, and a discussion about the need for further action

- The results of the corrective action investigation

- A corrective action decision will be made based on initial screening of alternatives, evaluation of alternatives, and comparison of alternatives

- The recommended alternative

\subsection{Records Availability}

Historic information and documents referenced in this plan are retained in the DOE project files in Las Vegas, Nevada, and can be obtained through written request to the DOE/NV Project Manager. 


\subsection{References}

AEC, see U. S. Atomic Energy Commission.

APHA, see American Public Health Association.

American Public Health Association. 1992. Gross Alpha and Gross Beta Radioactivity, Standard Methods for the Examination of Water and Wastewater, 18th edition. Washington, DC.

BN, see Bechtel Nevada.

Bechtel Nevada. 1995. Nevada Test Site Performance Objective for Certification of Nonradioactive Hazardous Waste. Las Vegas, NV.

Bechtel Nevada. 1996. Flood Assessment and Hazard Mitigation Design Recommendations for the Area 23 Landfill and Sewage Lagoons, Nevada Test Site, Nye County, Nevada. Prepared from data collected by Julianne Miller in 1996. Las Vegas, NV.

Bielawski, J.P. REECo. 1993. Memorandum (including polaroid photographs) to E.W. Kendall: "Unauthorized Discharges of Wastewater Near Quonset Hut 800, Area 23," 15 September. Mercury, NV.

CFR, see Code of Federal Regulations.

Code of Federal Regulations. 1993. 40 CFR 261.24. "Identification and Listing of Hazardous Waste." Washington, DC: U.S. Government Printing Office.

Code of Federal Regulations. 1996. 40 CFR 261. "Identification and Listing of Hazardous Waste." Washington, DC: U.S. Government Printing Office.

Code of Federal Regulations. 1997b. 40 CFR 262. "Standards Applicable to Generators of Hazardous Waste." Washington, DC: U.S. Government Printing Office.

Code of Federal Regulations. 1997a. 49 CFR 172. "Hazardous Materials Table, Special Provisions, Hazardous Materials Communications, Emergency Response Information, and Training Requirements." Washington, DC: U.S. Government Printing Office.

Daley, E.M. 1968. Memorandum to D.D. Smith, Chief, Farm Support Section: "Control of Aquatic Vegetation, Area 15 Irrigation Reservoir," 29 February.

DOE, see U.S. Department of Energy. 
DOE/NV, see U.S. Department of Energy, Nevada Operations Office.

Douglas, Richard L. 1967. Status of the Nevada Test Site Experimental Farm, Summary Report for July 1964-December 1965, January 17, 1967, Southwestern Radiological Health Laboratory, SWRHL-36r. Las Vegas, NV.

EG\&G Energy Measurements. 1993. Photo Number 7366-006, 17 February. Las Vegas, NV: Remote Sensing Laboratory.

Envirogard. 1997. Data Sheet, "Envirogard Test Kits and Accessories for On-Site Screening of Industrial Contaminants." Bedford, MA: Millipore Corporation.

EPA, see U.S. Environmental Protection Agency.

FFACO, see Federal Facility Agreement and Consent Order.

Federal Facility Agreement and Consent Order. 1996. Agreed to by the State of Nevada, the U.S. Department of Energy, and the U.S. Department of Defense.

Holmes and Narver. 1971. As-Built Drawing No. 015-094-C3.2, "Nevada Test Site-Area 15 Modifications to Building 15-06-USPHS Farm Plan, Profile, and Detail." Las Vegas, NV.

Holmes and Narver. 1974. As-Built Drawing No. 015-06-C1, "Nevada Test Site-Area 15 New EPA Slaughter Facility Grading Plan.” Las Vegas, NV.

IT Corporation. 1997a. Field Notes for CAU 340 site visit by F. Baird (IT), J.Wightman (IT/MACTEC), and J. Harrington (IT/SAIC), August 1997. Las Vegas, NV.

IT Corporation. 1997b. Preliminary Research Notes about Historical research conducted by R. Boehlecke and J. Herrington from July-October. Las Vegas, NV: IT/SAIC.

Liebendorfer, P.J. Nevada Division of Environmental Protection. 1997. Letter to Michael Giblin, DOE/NV, Regarding CAU/CAS changes and additions to the FFACO, 1 December. Carson City, NV.

NAC, see Nevada Administrative Code.

Neagle, C.C. REECo. 1994. Memorandum to R.L. Dodge and E.W. Kendall, "Transfer of File-Sample Results For Ditch at Quonset 800," 28 November. Las Vegas, NV: REECo.

Nevada Administrative Code. 1990. NAC444.940-444.9555 "Solid Waste Disposal." Carson City, NV. 
Nevada Administrative Code. 1996a. NAC445A.345-445A.22755 "Corrective Action Regulations." Carson City, NV: Nevada Division of Environmental Protection.

Nevada Administrative Code. 1996b. NRS459.9973, 459.9975 and 459.9977 "Nevada Revised Statutes." Carson City, NV: Nevada Division of Environmental Protection.

NDEP, see Nevada Division of Environmental Protection.

Nevada Division of Environmental Protection. 1995. Mutual Consent Agreement Between the State of Nevada and the U.S. Department of Energy for the Storage of Low-Level Land Disposal Restricted Mixed Waste, 6 June. Carson City, NV.

REECo, see Reynolds Electrical \& Engineering Company, Inc.

Reynolds Electrical \& Engineering Company, Inc. 1993a. Amended Closure Plan Area 23 Landfill Hazardous Waste Trenches, Phase II Report. Prepared for U.S. Department of Energy, Nevada Operations Office, Environmental Restoration Program. Las Vegas, NV.

Reynolds Electrical \& Engineering Company, Inc. 1993b. Certification and Closure Report Area 23 Landfill Hazardous Waste Trenches. Prepared for U.S. Department of Energy, Nevada Operations, Office Environmental Restoration Division. Las Vegas, NV.

Reynolds Electrical \& Engineering Company, Inc. 1993c. Stop Work Order EC-93-2069 Inv. 3136. Effective Date and Time: September 14, 1993 @, 1730 hours. Responsible Manger:

Kendall, E.W. Mercury, NV.

Robie, L., S. Reiner, and G. Locke. 1995. Ground-Water Data for the Nevada Test Site, 1992, and for Selected Other Areas in South-Central Nevada, 1952-92, U.S. Geological Survey Open-File Report 95-284.

Taylor, T.E. REECo. 1994. Memorandum to K.A. Hoar, "Use of Steam Jenny at Quonset Hut 800," 18 April. Mercury, NV.

U.S. Atomic Energy Commission. 1951. As-Built Drawing No. ATS-J/5004, "Sewage Treatment Plant General Plan." Los Alamos, NM: Los Alamos National Laboratory.

U.S. Department of Energy. 1981. As-Built Drawing 23-C31, "Hi-Pot Test Facility Disposal Plant Site Plan and Section." Las Vegas, NV: REECo.

U.S. Department of Energy. 1992. Environmental Measurements Laboratory Procedures Manual. HASL-300, 27th edition, Vol. 1. New York, NY. 
U.S. Department of Energy, Nevada Operations Office. 1994a. Project Management Plan, Rev. 0. Las Vegas, NV.

U.S. Department of Energy, Nevada Operations Office. 1994b. ERD-05-701, Rev. 0, Sampling Equipment Decontamination, Las Vegas, NV.

U.S. Department of Energy, Nevada Operations Office. 1994c (as amended). Standard Operating Procedure Manual. Las Vegas, NV: DOE/NV.

U.S. Department of Energy, Nevada Operations Office. 1996a. Final Environmental Impact Statement for the Nevada Test Site and Off Site Locations in the State of Nevada, DOE/EIS 0243. Las Vegas, NV.

U.S. Department of Energy, Nevada Operations Office. 1996b. Health and Safety Plan, Rev. 2, Environmental Restoration Project. Las Vegas, NV.

U.S. Department of Energy, Nevada Operations Office. 1996c. Housekeeping Category CAU Work Plan, Rev. 0. Las Vegas, NV.

U.S. Department of Energy, Nevada Operations Office. 1996d. Industrial Sites Quality Assurance Project Plan, Nevada Test Site, Nevada, DOE/NV--372. Las Vegas, NV.

U.S. Department of Energy, Nevada Operations Office. 1996e. Nevada Test Site Waste Acceptance Criteria, NTSWAC, Rev. 0. Las Vegas, NV.

U.S. Department of Energy, Nevada Operations Office. 1996f. Nevada Test Site/Yucca Mountain Project Radiological Control Manual, DOE/NV 11718-079. Prepared with data collected by A.L. Gile. Las Vegas, NV.

U.S. Department of Energy, Nevada Operations Office. 1997. Annual Report RCRA Post-Closure Monitoring and Inspections for the Mercury Landfill Hazardous Waste Trenches for the Period October 1995 - October 1996, DOE/NV 11718-092 UC-712. Las Vegas, NV: Environmental Restoration Division.

U.S. Environmental Protection Agency. 1978. Agronomic Practices of the Nevada Test Site Experimental Dairy Farm from 1974 through 1977, Environmental Monitoring and Support Laboratory, EMSL-LV-0539-21. Las Vegas, NV.

U.S. Environmental Protection Agency. 1980. Status Report of Area 15 Experimental Dairy Farm: Dairy Husbandry January 1977-June 1979 Agronomic Practices January 1978-June 1979, Environmental Monitoring and Support Laboratory, EMSL-LV-0539-32. Las Vegas, NV. 
U.S. Environmental Protection Agency. 1994. Guidance for the Data Quality Objectives Process, EPA QA/G-4. Washington, DC.

U.S. Environmental Protection Agency. 1996. Test Methods for Evaluating Solid Waste, Physical/Chemical Methods, SW-846, $3^{\text {rd }}$ edition, CD ROM. Washington, DC.

U.S. Geological Survey. 1973. Water Quality and Physical Characteristics of Nevada Test Site Water-Supply Wells, NTS-242, USGS-474-158.

U.S. Geological Survey. 1983a. "Camp Desert Rock Quadrangle, Nevada-Nye County," 7.5 Minute Series, Topographic Map.

U.S. Geological Survey. 1983b. "Mercury Quadrangle, Nevada-Nye County," 7.5 Minute Series, Topographic Map.

U.S. Geological Survey. 1986a. “Oak Spring Butte Quadrangle, Nevada-Nye County,” 7.5 Minute Series, Topographic Map.

U.S. Geological Survey. 1986b. "Oak Spring Quadrangle, Nevada-Nye County," 7.5 Minute Series, Topographic Map.

Winograd, I.J., and W. Thordarson. 1975. Hydrogeologic and Hydrochemical Framework, Southcentral Great Basin, Nevada-California, with Special Reference to the Nevada Test Site, U.S. Geological Survey Professional Paper 712-C. Washington, DC: U.S. Geological Survey. 


\section{Appendix A}

Data Quality Objectives Process Summary 


\section{A.1.0 Introduction}

The results of the Data Quality Objectives (DQO) process for the Corrective Action Unit 340, as provided in this appendix, are the foundation of the Corrective Action Investigation Plan (CAIP). The DQO process was conducted during a series of meetings between the U.S. Department of Energy, Nevada Operations Office; the State of Nevada Department of Environmental Protection; and subcontractor personnel. An informational meeting was held on July 15, 1997, to distribute site background and contamination information; a site tour was also conducted during this meeting. A DQO kickoff meeting was held on July 30,1997 , to discuss and plan the elements of the CAU investigation. Table A.1-1 lists the DQO process participants and their roles. The DQO followed the seven steps outlined by the U.S. Environmental Protection Agency's Guidance for the Data Quality Objectives Process (EPA, 1994).

The goal of the DQO process is to establish the quantity and quality of environmental data needed to support a decision on closure of the CAU. The process is intended to ensure that the information collected will provide sufficient and reliable information to identify, evaluate, and technically defend a corrective action.

The DQOs for site investigations were also developed to adhere to the precision, accuracy, representativeness, comparability, and completeness parameters, as discussed in the Industrial Sites Quality Assurance Project Plan (QAPP) (DOE/NV, 1996d).

\section{A.1.1 Site Location}

The CAU 340 is located at Area 15 and Area 23 of the Nevada Test Site (NTS) in Nye County, Nevada (Figure 1-2, CAIP). Included in CAU 340 are three Corrective Action Sites (CASs), 23-21-01 Quonset Hut 800 (Q800), 23-18-03 Skid Huts, and 15-18-02 Quonset Hut 15-11 (Q15-11). These sites are associated with the storage, mixture, and/or release of pesticides and herbicides. 
Table A.1-1

Data Quality Objectives Process Participants and Roles

\begin{tabular}{|l|c|c|c|}
\hline \multirow{2}{*}{ Participant } & \multicolumn{3}{|c|}{ Participant Role } \\
\cline { 2 - 4 } & $\begin{array}{c}\text { Scoping Team } \\
\text { Member }\end{array}$ & $\begin{array}{c}\text { Core Decision Team } \\
\text { Member }\end{array}$ & $\begin{array}{c}\text { Primary Decision } \\
\text { Maker }\end{array}$ \\
\hline \hline Janet Appenzeller-Wing, DOE/NV & $\mathrm{X}$ & & $\mathrm{X}$ \\
\hline Clayton Barrow, DOE/NV & $\mathrm{X}$ & $\mathrm{X}$ & $\mathrm{X}$ \\
\hline Harry van Drielen, NDEP & $\mathrm{X}$ & & \\
\hline Dean Miereau, NDEP & $\mathrm{X}$ & & \\
\hline Kenneth Beach, IT & $\mathrm{X}$ & & \\
\hline Robert Boehlecke, SAIC & $\mathrm{X}$ & & \\
\hline Frank Baird, IT & $\mathrm{X}$ & & \\
\hline Juliana Herrington, SAIC & $\mathrm{x}$ & & \\
\hline Syl Hersh, IT & $\mathrm{x}$ & $\mathrm{X}$ & \\
\hline Mary Todd, SAIC & $\mathrm{X}$ & $\mathrm{X}$ & \\
\hline Jeanne Wightman, MACTEC & $\mathrm{X}$ & $\mathrm{X}$ & \\
\hline Dave Madsen, BN & $\mathrm{x}$ & & \\
\hline Steve Nacht, BN & & & \\
\hline Angela Olson, BN & & & \\
\hline
\end{tabular}

$D O E / N V=$ U.S. Department of Energy, Nevada Operations Office

NDEP = Nevada Division of Environmental Protection

IT = International Technology Corporation

SAIC = Science Applications International Corporation

BN = Bechtel Nevada

MACTEC = Management Analysis Company Technologies 


\section{A.2.0 Conceptual Model(s)}

\section{A.2.1 Contaminants of Potential Concern}

The primary COPCs identified for CAU 340 are expected to be pesticides, herbicides, and related compounds based on preliminary sampling results at Q800 (Figure 2-5 and Table 2-1, CAIP), Skid Huts (Figure 2-6 and Table 2-2, CAIP), and Q15-11 (Figure 2-7 and Table 2-3, CAIP) and process knowledge. No evidence exists of volatile organic compounds (VOCs) or semivolatile organic compounds (SVOCs) being released at the CASs. However, these compounds could have been components of pestcides or herbicides and will be analyzed for as a precautionary measure. There is no indication of the use of polychlorinated biphenyls (PCBs) at these sites. Therefore, the samples will not be analyzed for PCBs. Samples will be analyzed for RCRA metals as a precaution because arsenic and selenium have historically been used as pesticides; however, there is no evidence to indicate their specific use at the NTS. The Toxicity Characteristic Leaching Procedure (TCLP) analyses will be conducted for metals and pesticides to show what portion of the analytes are soluble. The intent of the TCLP procedure is to simulate the conditions that may be present in a landfill where water may pass through the landfilled waste and travel into the groundwater carrying the soluble materials with it. Operations at the CASs were not associated with radionuclides, but as a precaution, the areas will be surveyed for radionuclides. Field screening will be conducted for VOCs, total petroleum hydrocarbons (TPH), chlordane, and DDT. A full suite of analyses will include:

- Total VOCs

- Total SVOCs

- Total RCRA metals

- Total pesticides

- TCLP metals and pesticides

- Total herbicides

- TPHs (gasoline and diesel)

- Gross alpha and beta

- Gamma spectroscopy 


\section{A.2.2 Conceptual Site Model(s)}

The conceptual models for CAU 340 were used as the basis for the DQO discussions. The primary assumption applicable to all of the CASs is that COPCs are localized to the investigation area and are of limited vertical and lateral extent.

At Q800, the COPCs:

- Occur in the upper part of the Q800 ditch where the clay and metal drainage pipes discharged (outfall area). This area is expected to be worst-case for vertical extent and concentration of COPCs.

- Could occur in the mounds of soil scraped from the ditch bottom and placed on either bank

- Have not been released from the investigation area (Figure 2-1, of the CAIP). If COPCs extend beyond the intersection of CAU 340 and the flood control channel, then those contaminants will be investigated under the CAU 444 Mercury Landfill.

- Could occur in the residue inside the drainage pipes (clay, metal). These pipes will be managed and disposed of at the conclusion of the investigation.

At the Skid Huts investigation area, the COPCs:

- Occur in areas that are stained, near the hose bibb, and where the sink discharged to the ground

- Are limited to the investigation area (Figure 2-2 and Figure 2-3, of the CAIP). If COPCs occur beyond the investigation area, then further evaluation is required.

At Q15-11, the COPCs:

- Occur in the soil under the plywood flooring

- Are limited to the investigation area of the Q15-11 building (Figure 2-4, CAIP). If COPCs occur beyond the investigation area, then rescoping is necessary.

The above assumptions are reasonable because the physical and chemical characteristics of the COPCs (e.g., pesticides and herbicides), the arid environmental conditions (e.g., low precipitation, high evapotranspiration, high temperatures), and soil type (e.g., development of durapan or caliche layers) are generally not conducive to deeper infiltration. These combined conditions are not 
favorable for wide-spread migration of COPCs. Modifications to these conceptual models based on additional or new information will be contained in the CAIP. 


\section{A.3.0 Problem Statement}

The problem is the release of pesticides, herbicides, and possibly other related compounds to the soil at levels that exceed or could exceed regulatory limits at each of the identified CASs. At Q800, pesticide and herbicide container rinsate was discharged to the ditch through an overflow drain from a solids/oil separator used to contain steam-cleaning effluent and from sinks that drained directly to the ditch. The Skid Huts site was used for storage of pesticides and herbicides. Any excess pesticide or herbicide solution not used at a specified location was returned and disposed of directly to the ground near the huts. The Q15-11 site was used for storage of pesticides and herbicides, and stained areas indicate that some of the product may have been spilled. However, the existing data for theses sites are insufficient to make corrective action decisions. The remaining DQOs describe the decisions, inputs, and decision rules that have been identified to guide the investigation of these sites to ensure that the data collected are of sufficient quantity and quality to make a defensible corrective action decision. 


\section{A.4.0 Identify the Decisions}

The decisions considered are those that are concerned with the corrective action options found in the FFACO. These options are clean closure (e.g., removal of material and closure of the site), closure in place (e.g., fill and cap the site), and no further action (e.g., no contamination is found above action levels). The primary decisions that will be used to guide the site investigations include:

- Decide when enough data have been collected for sufficient evaluation of the COPCs within the investigation area.

- Decide conditions which require a contingency plan to be implemented.

- Define when the investigation should be modified, rescoped, or continued under another CAU.

- Evaluate sampling analyses, methods, and approaches that will minimize the volume of pesticide and herbicide-contaminated, investigation-derived waste (IDW) (including backfilling) and ensure these options are adequate for site investigations.

- Decide which corrective action(s) are appropriate for the sites including closure in place and clean closure. This decision will be evaluated in the corrective action decision document (CADD). 


\section{A.5.0 Inputs: Information Needed to Resolve the Decisions}

Inputs are those elements of information needed and used to support the decision making process. These inputs include those shown in Table A.5-1.

Table A.5-1

Inputs for the Decision Making Process

\begin{tabular}{|l|l|}
\hline \multicolumn{1}{|c|}{ Inputs } & \multicolumn{1}{c|}{ Source of Information } \\
\hline COPC Identification & $\begin{array}{l}\text { Analyze soils by field-screening and laboratory methods for COPCs as listed in } \\
\text { Table 3-2 of the CAIP. }\end{array}$ \\
\hline $\begin{array}{l}\text { Action Level } \\
\text { Exceedence }\end{array}$ & $\begin{array}{l}\text { Compare detectable analytes to established preliminary action levels as } \\
\text { prescribed in Section 3.3 of the CAIP. }\end{array}$ \\
\hline COPC Distribution & $\begin{array}{l}\text { Collect soil samples from the surface and shallow subsurface, as needed, } \\
\text { throughout the investigation areas. Section 4.0 CAIP. }\end{array}$ \\
\hline Risk Evaluation & $\begin{array}{l}\text { Collect data of sufficient quantity and quality to support a risk evaluation and } \\
\text { establishment of risk-based action levels based on Nevada Administrative } \\
\text { Code 445A (NAC, 1996) }\end{array}$ \\
\hline Waste Management & $\begin{array}{l}\text { Collect data to support waste management and disposal according to } \\
\text { applicable standards as listed in Section 5.0 of the CAIP. }\end{array}$ \\
\hline $\begin{array}{l}\text { Potential Corrective } \\
\text { Actions }\end{array}$ & $\begin{array}{l}\text { Collect data of sufficient quantity and quality to support evaluation and } \\
\text { scientifically defensible corrective action(s) at the sites. }\end{array}$ \\
\hline
\end{tabular}




\section{A.6.0 Define the Study Boundaries and Constraints}

\section{A.6.1 Geographic Investigation Area}

The geographic investigation area for Q800 is shown in Figure 2-1, of the CAIP; for the Skid Huts, see Figure 2-2 and Figure 2-3, of the CAIP; and for Q15-11, see Figure 2-4, of the CAIP. The following are included within the boundaries of the investigation area:

- Waste management area

- Decontamination area

- Field monitoring or screening area

- Sample handling area

- Other areas as needed (e.g., equipment staging area)

\section{A.6.2 Spatial and Temporal Boundaries}

Spatial boundaries are concerned with the distribution of COPCs. The COPCs for these sites are assumed to be limited in extent (see conceptual models, Section 3.1, of the CAIP).

The temporal boundaries are concerned with the migration, degradation, or increasing COPC concentrations at the CASs. The COPCs are assumed to be biodegrading over time, and there is no indication that COPCs are migrating or increasing at these sites. These assumptions are valid because the chemical characteristics of the COPCs make them relatively immobile and because of the arid environment (see conceptual models, Section 3.1, of the CAIP). The COPCs are assumed not to be increasing because practices associated with the release of COPCs (i.e., diposal of excess pesticide or herbicide solution or rinsate to the ground) have been stopped so that further contamination will not occur.

\section{A.6.3 Constraints on the Investigation}

The investigation sampling activities are currently scheduled to be conducted early in 1998 . The constraints on this schedule and actual sampling activities are as follows:

- Approval of the CAIP: approval of the CAIP serves as the starting point for data collection activities, including field instructions and site-specific health and safety plans. 
- Inclement weather: (i.e., weather conditions could adversely affect the health and safety of personnel or data quality.)

- Topographic or geologic limitations: if sampling methods become severely hampered by sample location, caliche, alluvial debris, or other similar conditions, the sampling strategy will need to be reevaluated.

- Steam-cleaning operations at Q800 CAS: the steam-cleaning pad is currently in use on a daily basis. However, the clay drainage pipe from the solids/oil separator to the ditch is sealed. Measures will be taken to ensure these operations do not impact the investigation.

- Hose bibb at the Skid Huts CAS: the hose bibb is leaking slightly and needs to be repaired. The water to the hose bibb needs to be turned off and/or tagged "out-of-service" prior to and during the investigation.

- Existing skid hut at the Skid Huts CAS: the existing skid hut needs to be removed prior to soil sampling at the investigation site.

- Currently approved pestcides and herbicides are stored in sealand containers (south east) of the Skid Huts site. Present operations associated with the use of these products must be evaluated so no adverse interference will occur with the site investigation.

- Plywood flooring at the Q15-11 CAS: The plywood flooring will be stacked and protected from the elements. A sample will be collected for waste management determination.

- Environmental concerns: evaluations for the presence of threatened and endangered species and cultural resources are required prior to the investigation.

- Radiological concerns: the current assumption is that no radiological constituents are present at the site; information from field surveys contrary to this assumption would require reevaluation of the investigation strategy. 


\section{A.7.0 Develop a Decision Rule}

The primary decision to be made is whether the data collected during the investigation process are of sufficient quality to meet investigation objectives and support a scientifically defensible corrective action decision (i.e., when will the investigation stop). The data collected during the field investigation will correlate field and laboratory results to determine if COPC concentrations exceed the preliminary action levels (PALs), as identified in Section 3.3 of the CAIP. The investigation will continue if COPC concentrations consistently exceed the stated action levels as long as it is reasonable and cost-effective to do so. The investigation will stop when COPC concentrations are consistently below the stated PALs.

The following information and actions levels will be used to resolve site investigation issues:

\section{A.7.1 Stopping points and notification}

The stopping points of the investigation and notification of the DQO members will occur if:

- Conditions become imminently dangerous to the health and safety of workers

- Conditions and/or COPCs are significantly different than the conceptual model (e.g., extensive radiation contamination)

- Sufficient soil samples have been collected from the investigation area to make an adequate evaluation of the presence of COPCs at the site, as determined by PALs.

\section{A.7.2 Contingency plans}

Contingency plans will be implemented when COPCs extend beyond the capability of the selected sampling method and a different sampling method is required to complete the investigation.

\section{A.7.3 Rescope, Modify, or Continue Investigation}

The investigation and sampling activities will be:

- Rescoped if conditions and/or COPCs are significantly different than the model

- Modified and/or continued if COPCs extend beyond the investigation area and it is reasonable and practical to continue with the current investigation 
- Rescoped and the COPCs investigated under a different CAU if COPCs extend beyond the investigation area and it is reasonable and practical to discontinue the current investigation

\section{A.7.4 Analytical Methods}

The primary analytical methods (Table 3-2, of the CAIP) include EPA Test Methods for Evaluating Solid Waste, 3rd Edition, Parts 1-4, SW 846 (1996) and are based on expected COPCs. Additional radionuclide analytical methods will come from the Prescribed Procedures for Measurement of Radioactivity in Drinking Water (EPA, 1980) and the Environmental Methods Laboratory Procedure Manual, HASL-300 (DOE, 1992).

\section{A.7.5 Sampling methods and investigative approach}

The sampling method and investigative approach are contingent upon:

- Physical conditions at the site

- Evaluation of hand sampling, trench/test pit excavation, and drilling methods

- Investigation needs

- Cost-effectiveness

- Expected depth of COPCs

- Evaluation of a staged sampling approach

- Investigation and laboratory time constraints 


\section{A.8.0 Decision Errors}

Decision Error I is the overestimation of the extent of contamination resulting in excessive and unnecessary corrective action. Decision Error II is the underestimation of the extent of contamination resulting in failure to adequately address the closure of a site in accordance with FFACO requirements.

The consequence of Decision Error I is the expense associated with the implementation of an unnecessary or overly excessive corrective action. The consequence of Decision Error II is the possibility of human exposure to COPCs above action levels in the soil. Decision Error II has the more severe consequences associated with it because of the possibility of human exposure. 


\section{A.9.0 Optimize the Design}

The planned field investigation will occur in two sampling stages. This two-staged approach has been identified as optimal for the investigation of CAU 340 and will allow for a resource-effective design that satisfies the DQOs.

\section{A.9.1 Stage / Sampling}

Stage I sampling:

- Use of hand tools (manual or powered) for the collection of soil samples throughout the investigation area over a wide scale and at expected worst-case areas

- Analysis for a broad suite of parameters to identify the types, concentration, and general extent of COPCs

- Identification of maximum probable vertical extent (at expected worst-case areas)

- Selected samples may have laboratory analyses conducted in a quick turn-around fashion at the Q800 or Skid Huts to assist in guiding Stage II sampling efforts

- Correlation of laboratory and field-screening results

\section{A.9.2 Stage /I Sampling}

Stage II sampling:

- Based on Stage I analytical results

- Collection of additional soil samples on a narrower scale or from targeted areas throughout the investigation area, as needed

- Analysis modified (e.g., reduced or expanded) if justified by Stage I results

- Continued use of hand tools for soil sample collection. If COPCs are above action levels and extend beyond about $2 \mathrm{~m}(\sim 6 \mathrm{ft})$, or if soil conditions make the use of hand tools ineffective for sampling, then contingency plans for trenching or drilling could be implemented.

- Modification of (reduce or expand) the range of parameters to be analyzed for based on Stage I analytical results. 
Appendix B

Project Organization 


\section{B.1.0 Project Management}

The DOE/NV Project Manager is Janet Appenzeller-Wing. She can be contacted by telephone at (702) 295-0461.

The identification of the project Health and Safety Officer and the Quality Assurance Officer can be found in the DOE Field Management Plan. However, personnel are subject to change, and it is suggested that the Project Manager be contacted for further information. The Task Manager will be identified in the FFACO Biweekly Activity Report prior to the start of field activities. 


\section{Distribution}

Paul J. Liebendorfer

2 (Controlled)

State of Nevada

Bureau of Federal Facilities

Division of Environmental Protection

333 W. Nye Lane, Room 138

Carson City, NV 89706-0851

Donald A. Garrepy

1 (Controlled)

State of Nevada

Bureau of Federal Facilities

Division of Environmental Protection

555 E. Washington, Suite 4300

Las Vegas, NV 89101

Sabrina Bonnell

1 (Controlled)

Environmental Restoration Division

DOE/Nevada Operations Office

P.O. Box 98518, M/S 505

Las Vegas, NV 89193-8518

Janet Appenzeller-Wing

Environmental Restoration Division

1 (Uncontrolled)

DOE/Nevada Operations Office

P.O. Box $98518, \mathrm{M} / \mathrm{S} 505$

Las Vegas, NV 89193-8518

Clayton Barrow

1 (Uncontrolled)

Environmental Restoration Division

DOE/Nevada Operations Office

P.O. Box $98518, \mathrm{M} / \mathrm{S} 505$

Las Vegas, NV 89193-8518

Angela Olson

1 (Uncontrolled)

Bechtel Nevada

P.O. Box 98521, M/S NTS306

Las Vegas, NV 89193-8521

Steve Nacht

1 (Uncontrolled)

Bechtel Nevada

P.O. Box 98521 , M/S NTS306

Las Vegas, NV 89193-8521 
Ken Beach

IT Corporation

P.O. Box 93838

Las Vegas, NV 89193

Mary Todd

SAIC

P.O. Box 93838

Las Vegas, NV 89193

Mark DiStefano

IT Corporation

P.O. Box 93838

Las Vegas, NV 89193

Juliana Herrington

SAIC

P.O. Box 93838

Las Vegas, NV 89193

IT Corporation Central Files

IT Corporation

P.O. Box 93838

Las Vegas, NV 89193
1 (Uncontrolled)

1 (Uncontrolled)

1 (Uncontrolled)

1 (Uncontrolled)

1 (Uncontrolled) 


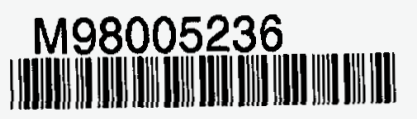

Report Number (14) DOE/NV -495

Publ. Date (11)

$$
199801
$$

Sponsor Code (18)

$\frac{D O E / D P, X F}{U C-700, D O E / E R}$

UC Category (19)

\section{$1998062206 j$}

